\title{
On a neck, on a spit: controls on the shape of free spits
}

\author{
A. D. Ashton ${ }^{1}$, J. Nienhuis ${ }^{1,2}$, and K. Ells ${ }^{3}$ \\ ${ }^{1}$ Woods Hole Oceanographic Institution, Geology and Geophysics Department, \\ Woods Hole, Massachusetts, USA \\ ${ }^{2}$ Massachusetts Institute of Technology, Earth, Atmospheric, and Planetary Sciences, \\ Cambridge, Massachusetts, USA \\ ${ }^{3}$ University of North Carolina Wilmington, Center for Marine Science, \\ Wilmington, North Carolina, USA \\ Correspondence to: A. D. Ashton (aashton@whoi.edu)
}

Received: 8 May 2015 - Published in Earth Surf. Dynam. Discuss.: 12 June 2015

Revised: 31 December 2015 - Accepted: 21 January 2016 - Published: 3 February 2016

\begin{abstract}
We investigate the controls upon the shape of freely extending spits using a one-contour-line model of shoreline evolution. In contrast to existing frameworks that suggest that spits are oriented in the direction of alongshore sediment transport and that wave refraction around the spit end is the primary cause of recurving, our results suggest that spit shoreline shapes are perhaps best understood as graded features arising from a complex interplay between distinct morphodynamic elements: the headland updrift of the spit, the erosive "neck" (which may be overwashing), and the depositional "hook". Between the neck and the hook lies a downdriftmigrating "fulcrum point" which tends towards a steady-state trajectory set by the angle of maximum alongshore sediment transport. Model results demonstrate that wave climate characteristics affect spit growth; however, we find that the rate of headland retreat exerts a dominant control on spit shape, orientation, and progradation rate. Interestingly, as a spit forms off of a headland, the rate of sediment input to the spit itself emerges through feedbacks with the downdrift spit end, and in many cases faster spit progradation may coincide with reduced sediment input to the spit itself. Furthermore, as the depositional hook rests entirely beyond the maximum in alongshore sediment transport, this shoreline reach is susceptible to high-angle wave instability throughout and, as a result, spit depositional signals may be highly autogenic.
\end{abstract}

1

Recurved barrier spits occur in a wide variety of environments, including passive sandy shorelines, delta complexes, and rocky coasts, where spits extend depositionally from a shore that is otherwise eroding. The variety of smooth, curved, wave-sculpted shapes of spits (Fig. 1) has long been of scientific interest and there are numerous studies and interpretations of spit growth and associated deposits (e.g., Schwartz, 1972); however, understanding of the basic controls on spit shape, evolution, and response to changes in forcing conditions remains elusive. Interpretations on the controls on spit orientation are often presented in the literature a posteriori (i.e., after the spit has been observed). As such, quantitative, "a priori" prediction of spit shape and ori- entation has previously been lacking. A mechanistic understanding of the drivers of spit shoreline shaping is vital if we are to predict their future evolution and to understand how these coastal landforms may record paleo-environmental information.

Here, we conduct a series of experiments with a numerical model of shoreline evolution to explore the environmental controls that influence spit growth and form. Using these model results, we present a quantitative, process-based description of key elements along a spit, including the erosional updrift neck and the depositional hook. A series of controlled model experiments suggest that even as the directional characteristics of approaching waves affect spit shape, the updrift boundary significantly affects spit growth. As such, the con- 

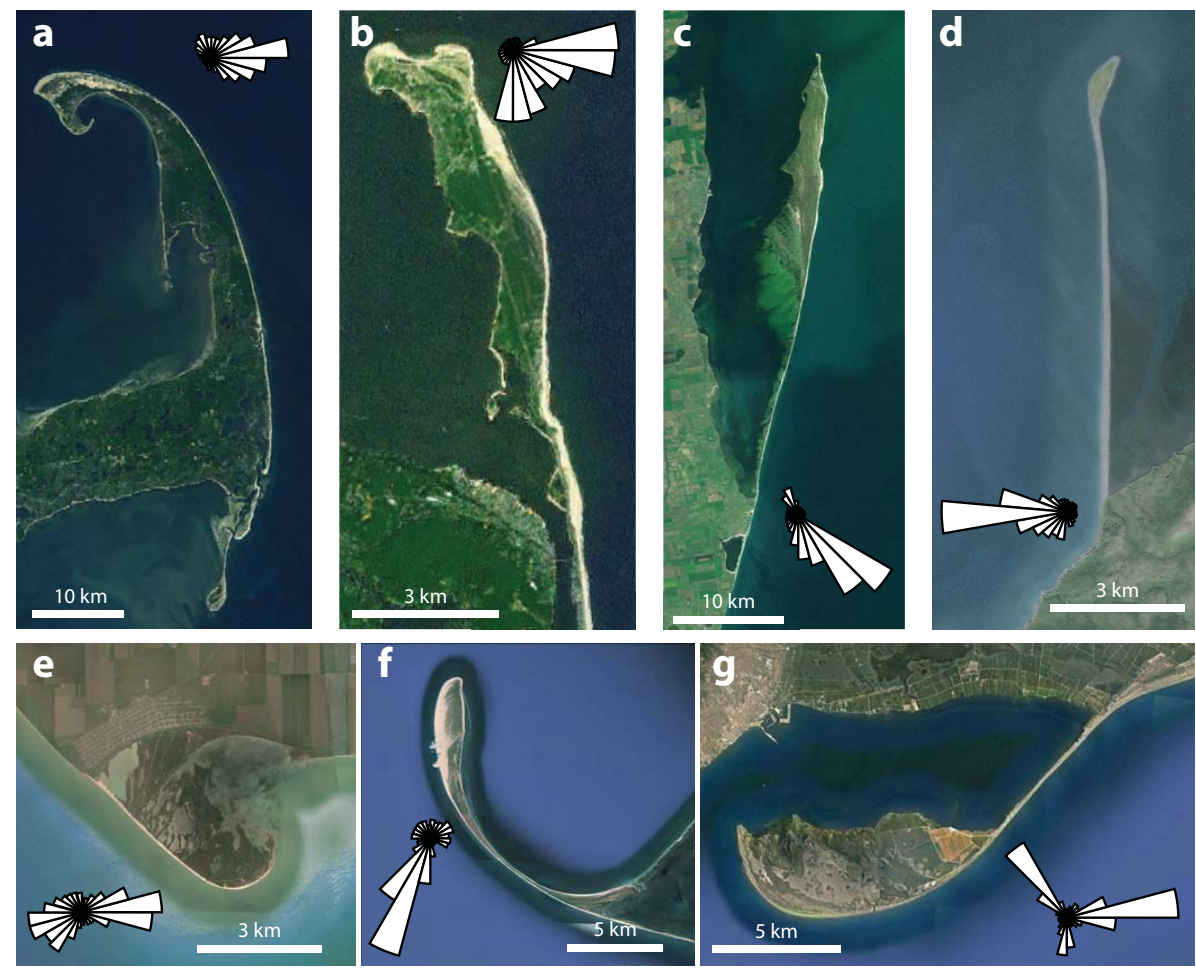

Figure 1. Natural examples of free spits: (a) Cape Cod, Massachusetts, USA; (b) Sandy Hook, New Jersey, USA; (c) Dzharylhach, Ukraine; (d) spit on Hagemeister Island, Alaska, USA; (e) Kamyshevatskaya Spit, Russia; (f) Ostriv Tendrivs'ka Kosa, Ukraine; and (g) La Banya Spit, Spain. Insets display the angular distribution of deep-water wave energy, (a-f) from WaveWatch III ${ }^{\circledR}$ (Chawla et al., 2013) and (g) from the Cap Tortosa wave buoy (Bolaños et al., 2009).

trols on spit shape are more complex than perhaps previously considered.

\section{Background}

Spits are detrital, non-cohesive (sandy or shingle) depositional features emanating from headland coasts, extending for many kilometers (Fig. 1). In plan view, spits are best identified through their curved end, which generally consists of a series of sub-parallel beach ridges indicative of shoreline progradation. Near the headland, spits are usually narrow, backed by an embayment or perhaps backbarrier marshes, and susceptible to barrier overwash (Schwartz, 1972). Just updrift of the zone of accretion and downdrift of the overwashing region, truncated beach ridges suggest a region of long-term erosion (Fig. 1). Spits typically extend off of shoreline protuberances, often from eroded or reworked headlands formed by other geologic processes (Davis, 1896; Roy et al., 1994). Spits are also common on wave-dominated deltaic coasts, such as the Ebro and Rhone River deltas (Raynal et al., 2009; Sanchez-Arcilla et al., 1998), with recent research suggesting that deltaic spit extension occurs most vigorously after delta lobe abandonment (i.e., when local flu- vial sediment supply is drastically reduced) (Nienhuis et al., 2013).

\subsection{Spit shape}

The growth of spits has long been attributed to currents carrying sediment along a coast that abruptly turns inwards (Gilbert, 1885), with the current depositing its sediment load as it slows into deep water. Gilbert (1885) considered spits to be formed in the direction of littoral transport, and attributed coastline recurving to waves from multiple directions. Gulliver (1899) also discussed the interaction between cliffs and extensional spits forming off of either end of "winged beheadlands" (here we use the more common "headland"). Inspired by the Provincetown Hook, extending off of the northern end of Cape Cod, Massachusetts, USA, and Sandy Hook, New Jersey, USA (Fig. 1a, b), Davis (1896) analyzed the growth of spits from eroding bluffs, using beach ridge patterns to discern a "fulcrum point" between erosion and accretion that migrates downdrift as a spit grows. Within his proposed framework of a maturing shoreline, Davis suggested that as spits grow their curvature changes and there is an increase in sediment delivery to the spit over time.

Johnson (1919) further detailed how headland erosion can cause erosional (transgressive) reworking of the updrift re- 
gion of a spit even as the recurved spit end depositionally extends offshore. Evans (1939) emphasized that spit growth is due to wave-driven transport (rather than to other oceanic currents), further providing a concept that has become common lore - that wave refraction is responsible for spit recurving. Bruun (1954) grounded the concepts that spits grow from littoral drift within a quantitative framework, in particular noting the role that a deep-water maximizing angle of $\sim 45-50^{\circ}$ in littoral transport may play in equilibrium shoreline forms and potentially in forming shoreline "bumps" located downdrift of this maximum point. Bruun also attributed spit recurving to refraction and diffraction processes at the spit end. Zenkovitch (1967) investigated a series of "free" spit forms (where spits do not grow into a tidal inlet or reconnect to shore), suggesting that spit orientation itself is set by the angle of maximum alongshore sediment transport of incoming waves.

More recent investigations suggest a connection between updrift and downdrift coastal segments. For instance, Héquette and Ruz (1991) emphasize the role played by headland supply rate and barrier overwash in the historical reshaping of spits. Lindhorst et al. (2010) infer increased growth of downdrift hooked spit segments to coincide with increased erosion of the updrift spit coast. Other studies also use depositional beach ridges and shoreline changes to interpret wind and wave climates (Jewell, 2007) and changes in marine driving conditions (e.g., Allard et al., 2008).

\subsection{Modeling of spit growth}

Numerical modeling has long been used to understand spit evolution. In perhaps the first numerical model of spit growth, King and Mc Cullagh (1971) apply a stochastic process-response model to reproduce spit ends that recurve as a consequence of waves approaching from differing directions. For the growth of simple spits, a mass balance approach provides a useful framework for calculating spit extension rates (Hoan et al., 2011; Kraus, 1999). Models have also been applied to understand short-term (decadalcentennial) changes in spit shorelines; for example, Jiménez and Sánchez-Arcilla (2004) model the combined effects of alongshore transport gradients and barrier overwash on the evolution of the La Banya spit extending off of the Ebro Delta, Spain (Fig. 1g).

Other modeling studies explore processes reshaping spit ends. Petersen et al. (2008) investigate presumed steady-state extension of a spit from a fixed headland position with waves approaching from a single angle (which is greater than the maximizing angle of $45^{\circ}$ ), and therefore a constant sediment supply. Using an analytical model, they suggest that the narrowest possible spit has the fastest growth rate, and with more detailed numerical modeling suggesting that spit width should be proportional to the surf zone width. These findings are upheld by more detailed morphodynamic modeling by Kaergaard and Fredsoe (2013a); again the authors further suggest that wave angle alone influences spit recurving. Research by López-Ruiz et al. (2012) also suggests that the hook recurve itself may result in alongshore transport gradients that lead to the formation of an undulation superimposed upon the curve, a phenomenon that occurs for both shore-parallel and more complex shoreface contours, and is stronger for the latter case. Notably, all of these investigations use a fixed updrift boundary condition and often use waves approaching from one angle. The former condition results in growth along the entire spit, with no concurrent updrift erosion as observed on many spits (Fig. 1).

In general, however, there have been few quantitative studies of free spit formation that include the entire spit system, from source to sink, and typically these studies focus on waves from only one direction. The research presented here builds upon (and modifies the interpretation of) previous modeling studies by Ashton et al. (2007) which suggested that the distribution of wave approach angles serves as the primary control on spit shape.

\subsection{Shoreline change and littoral transport}

Recent research has revealed richer understanding of how alongshore sediment transport sculpts the coast, exploring how the angle distribution of approaching waves strongly affects coastline evolution. The alongshore transport of littoral sediment primarily occurs within the surf zone, where breaking waves suspend large quantities of sediment that are advected downcoast by an alongshore current that is also driven by wave breaking. As waves approach shore, they shoal and refract, changing both their height and angle (Fig. 2) (Komar, 1998; Murray and Ashton, 2013). However, because refraction causes coincident changes to wave height and angle, gradients in $Q_{\mathrm{s}}\left(\mathrm{m}^{3} \mathrm{~s}^{-1}\right.$, deposited volume), the alongshore sediment transport along a coast, are best understood by looking at deeper-water wave quantities (Ashton and Murray, 2006a; Ashton et al., 2001), i.e., from the toe of the shoreface. The common CERC formula, along with many other formulas for the alongshore flux of sediment (Ashton and Murray, 2006b; Bruun, 1954), predicts a maximum in the littoral flux for a deep-water wave angle around $45^{\circ}$, assuming that shoreparallel contours extend from the shoreface toe (Fig. 2b).

There is a long history of modeling the plan-view evolution of a shoreline using the so-called "one-contour-line" or "one-line" approach (Komar, 1973; Larson et al., 1987; Pelnard-Consideré, 1956, 1984). If the gradients in the alongshore flux of sediment caused by breaking waves dominate the evolution of the shoreline and the shoreface maintains a fixed shape, the evolution of the coast can be understood by tracking a single contour line, such as the shoreline itself. Previously, shoreline evolution due to gradients in alongshore sediment transport and small breaking wave angles had been assumed to flatten, or diffuse, perturbations to a straight coast (Pelnard-Consideré, 1956; Larson et al., 1987) with a constant diffusivity assumed independent of wave 


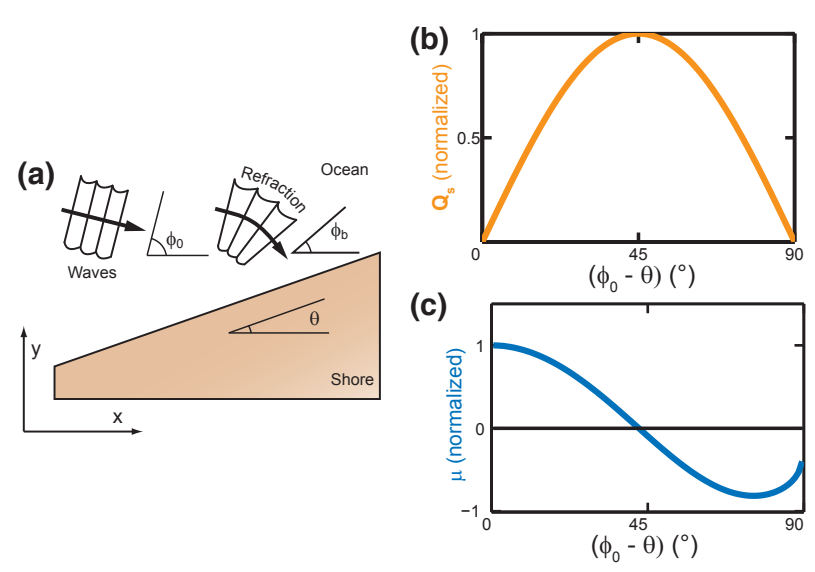

Figure 2. Key concepts of alongshore sediment transport and shoreline instability: (a) plan view showing axes and reduction of wave angle due to refraction, (b) normalized alongshore sediment transport, $Q_{\mathrm{s}}$, as a function of offshore wave angle, and (c) normalized shoreline shape diffusivity, $\mu$, as a function of deep-water wave angle.

angle. Ashton and Murray (2006a) show that the diffusive power of waves decreases as the wave angle increases towards the value maximizing alongshore sediment transport ( $\sim 45^{\circ}$, Fig. $\left.2 c\right)$. Beyond this maximum, for "high-angle" waves, perturbations to a shore can grow rather than diffuse. Because this instability is determined by the angle of deepwater waves, shoreline instability can (and usually does) occur even when waves break at angles much smaller than $45^{\circ}$. Note that we define shoreline instability in terms of whether perturbations to a straight coast will grow or flatten over time. A coast in this case may be stable or unstable regardless of whether it is eroding or accreting over the long term.

\section{Methods}

\subsection{Coastline Evolution Model}

We model spit growth off of preexisting headlands using the Coastline Evolution Model (CEM), a one-contour-line model that, by discretizing the plan-view domain into square cells, computes the evolution of a shoreline that can be arbitrarily sinuous, even doubling back on itself (Fig. 3a) (for full details see Ashton and Murray, 2006a). This model has been applied to understand a wide variety of coastline features, including alongshore sand waves, caped coasts, flying spits (Ashton and Murray, 2006a, b; Ashton et al., 2001), segmentation of elongated water bodies (Ashton et al., 2009), growth of asymmetrical deltas (Ashton and Giosan, 2011), and wave reworking of abandoned deltas (Nienhuis et al., 2013).

Each model day, waves (deep-water wave height $H_{0}=1 \mathrm{~m}$ and period $T=8 \mathrm{~s}$ for all results here) approach the shore from a deep-water angle (depth defined at the shoreface toe) randomly selected from a weighted probability distribution (a)
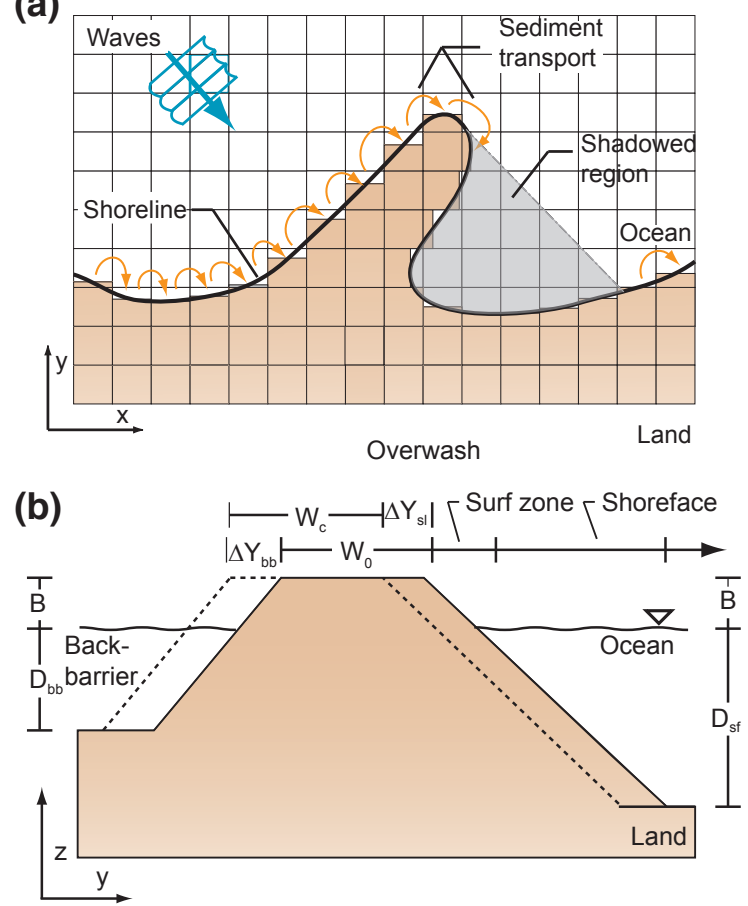

Figure 3. (a) Model schematic of CEM demonstrating discretization of the plan view into cells. For waves of given orientation and height, sediment is transported along the shoreline based upon the wave angle, and cell quantities are adjusted based on flux gradients. Note also the zone "shadowed" from wave approach: sediment transport does not occur in these shadowed regions. (b) Conceptualization of the cross-shore domain with a fixed shape shoreface and barrier overwashing. Alongshore sediment gradients in the surf zone are spread over the shoreface. If the spit width is below the critical width $W_{\mathrm{c}}$, sediment is transported from the front to the back of the barrier.

function. The model assumes shore-parallel contours and does not compute wave ray convergence or divergence. Although this simplified wave refraction treatment may reduce model accuracy at small scales and high shoreline curvature, these simplifications become more appropriate at large scales, generally that of kilometers (van den Berg et al., 2012; Falqués and Calvete, 2005), and are in keeping within our exploratory modeling approach (Murray, 2003, 2007). Sediment is transferred between shoreline cells according to the common "CERC" or "Komar" (1971) formula, and the sediment quantities in each shoreline cell are updated based upon the computed gradients in the alongshore sediment flux (Ashton and Murray, 2006a). No sediment transport occurs along coastlines that are shadowed from incoming waves by other portions of the shoreline (Fig. 3a).

As with all one-line models, the CEM approach assumes that sediment transport gradients in the surf zone are spread across the profile at a rate commensurate with that of longterm shoreline shaping. As closure depths are typically con- 
sidered at annual to decadal scales (Bruun, 1962; Hallermeier, 1981; Swift et al., 1985) the CEM is not necessarily appropriate for simulating shorter-term changes (Falqués et al., 2011), but should be appropriate for simulating accumulated shoreline change over the decadal to centennial scales of spit formation and growth. Similarly, the influence of storms on alongshore sediment transport is spread across time, integrated over the long-term wave climate.

As modeled spits grow off of headlands, they typically begin to erode into their previous deposits, eventually thinning and disconnecting from the updrift headland (Fig. 1). To reproduce the dynamics of natural spits, and to keep the shoreline continuous, when barriers thin below a minimum critical width (Leatherman, 1979, 1983) we implement overwash by transporting sediment landward using a geometric approach (Fig. 3b) (Ashton and Murray, 2006a). Although the overwash process can widen a barrier for the typical case where backbarrier depths are less than shoreface depths, for simplicity in these model runs we set the backbarrier depth, $D_{\mathrm{bb}}$, equal to the shoreface depth, $D_{\text {sf }}$. Therefore, overwash merely moves the backbarrier shoreline landwards in response to changes of the seaward shoreline and does not widen the barrier. In the model runs presented here, alongshore sediment transport gradients tend to subsequently accrete a coast after overwashing, thereby increasing the local barrier width to be slightly larger than the critical value. As such, the migration of the updrift headland coast tends to set the long-term rate of transgression of the overwashing spit.

Wave-approach-angle distributions in the model are controlled through two parameters to characterize the main aspects of a directional wave climate: wave direction and the proportion of high-angle waves (Ashton and Murray, 2006b). The wave asymmetry, $A$, represents the fraction of waves approaching from the left, looking offshore; for $A>0.5$ a straight coast would experience a net sediment transport to the right. The directional distribution of wave approach angles also has a strong influence on shoreline evolution (e.g., Ashton and Giosan, 2011), and the ratio $U$ represents the fraction of waves approaching from high angles $\left(>45^{\circ}\right)$. As $U$ increases, the net diffusivity of the wave climate decreases.

Our goal is to model the classic case of spits growing landward by extending off of a headland, and our first experiments span a littoral cell from headland source (nodal point) to spit sink (Inman, 2005). For all experiments we use $U<0.5$, such that headlands experience a net diffusive wave climate, in contrast to the case of spit growth in a highangle-wave environment as explored in other studies (Ashton et al., 2007; Kaergaard and Fredsoe, 2013b, c; Petersen et al., 2008). Even with a predominance of low-angle waves, larger values for $U$ result in more waves approaching from the sides of growing spits, which affects the recurving graded spit shape. Because we categorize the wave field into four $45^{\circ}$ bins, the wave distributions are relatively broad, a condition common for some, but not all, coasts (Fig. 1).
To aid the understanding developed in our exploratory model applications, we choose to reduce the effects of depth and height variation on spit evolution, leaving examination of these effects for future model experiments. Although tall bluffs and rocky headlands are often the sources of sediment for spits, the model shoreline extends off of an initial sandy headland with a fixed low height above sea level of $1 \mathrm{~m}$ (except in experiments with a controlled rate of headland erosion). Deposited sediment similarly extends to $1 \mathrm{~m}$ a.s.1 (above sea level) and, to eliminate mass balance effects of both shorefaces excavating the shelf or perched spits extending into deeper water, the shoreface depth is the same as the basin depth within the model domain $(15 \mathrm{~m}$ in most runs shown, although this is varied in one set of experiments). Barriers similarly extend $1 \mathrm{~m}$ a.s.l. and, because the basin has constant depth, the shoreface and backbarrier depths are the same such that overwash does not widen the barrier. These geometries are of course oversimplifications of natural cases - for example backbarrier regions typically are shallower than the open-ocean closure depth.

\subsection{Wave climate analysis}

To provide an in-depth quantitative understanding of the mechanisms of spit growth within the model, we compute local wave climate metrics along spit shorelines as a diagnostic tool (Ashton and Murray, 2006b). For any location along the shoreline, net long-term alongshore sediment transport, $Q_{\text {s,net }}$, can be computed by summing back-andforth littoral fluxes over time for all waves in the wave climate that will affect the coast. Similarly, coastline diffusivity, $\mu_{\text {net }}$, which quantifies net coastline stability or instability, can be summed over the entire wave climate using the local relative wave angle (Fig. 2c). Both alongshore sediment transport and coastline diffusivity are weighted by the deep-water wave characteristics $\left(H_{0}^{12 / 5} T^{1 / 5}\right)$, representing the wave height contribution to alongshore sediment transport, serving as an alongshore-flux-specific representation of "wave energy". Except where quantified, plots of $Q_{\text {s,net }}$ and $\mu_{\text {net }}$ are normalized by their alongshore maximum.

Shoreline shape, and correspondingly $Q_{\text {s, net }}$ and $\mu_{\text {net }}$, changes as the shoreline itself evolves; therefore we compute wave climate metrics separately from the model runs that evolved the spit shapes themselves. At selected timesteps, holding the shoreline fixed, we sum the net alongshore transport and shoreline diffusivity over a large series of random draws (typically 10000) from the wave angle climate distribution. Note that the net diffusivity, $\mu_{\text {net }}$, is different than the locally normalized stability metric, $\Gamma$, primarily utilized in Ashton and Murray (2006b), as $\mu_{\text {net }}$ is also weighted by how often waves impact the coast, thereby accounting for shadowing effects. 

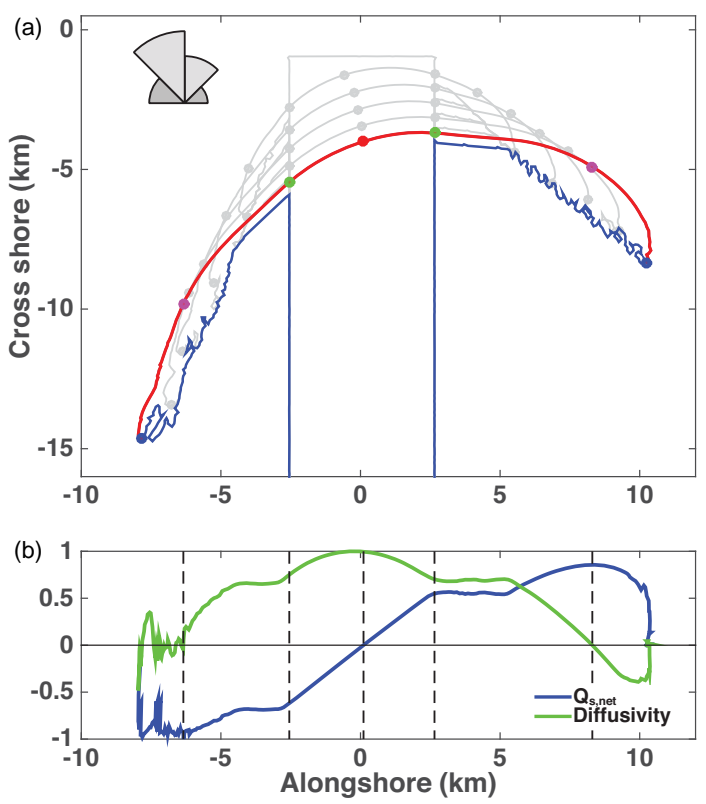

Figure 4. Model results showing (a) plan-view domain with spits growing off of an eroding headland experiencing asymmetrical wave conditions with (b) corresponding domain-normalized alongshore sediment transport and diffusivity. Results after 110 model years, with "ghost plots" every 22 model years. Red line indicates active spit shoreline and circles denote key morphologic locations: red circle is the nodal point, green circles are the locations of $Q_{\mathrm{s}, \text { in }}$, magenta circles are the fulcrum points, and blue circles are the spit ends where $Q_{\mathrm{s}}=0$. Inset of flux-normalized wave climate in top panel $(A=0.7, U=0.2)$.

\section{Spit growth off of freely eroding headlands}

\subsection{Spit growth in an asymmetric wave climate}

Starting from an initially rectangular sandy headland, an asymmetric wave climate causes spits to extend in both the net downdrift and updrift direction (Fig. 4). Growing spits off of each side of the headland have different orientations and curvature. Model animations (see movies in the Supplement) show that the spits generally evolve smoothly, although there are observable fluctuations in the shoreline, particularly on the downdrift reaches. In some cases, these fluctuations arise stochastically from the white noise randomness of the wave climate. However, longer-period, organized fluctuations at the spit ends also appear, and represent emergent (or autogenic) shoreline behavior.

Wave climate analysis reveals interesting aspects of the mechanisms of spit growth (Fig. 4b). As spits grow and the headland relaxes from the artificial initial condition, the nodal point (location where alongshore sediment transport reverses direction) migrates towards the center of the headland. Despite the wave asymmetry, each spit eventually is supplied with an approximately equal arc length of shoreline from the headland, with the nodal point migrating anal- ogously to a migrating drainage divide. Along the headland itself, a constant gradient in alongshore sediment transport develops, driving a spatially uniform rate of headland erosion. Alongshore sediment transport then becomes mostly constant along the spits, particularly where the spit is narrow and overwashing, then increases slightly towards the value of maximum transport (for that direction) before decreasing to zero at the spit end. Shoreline diffusivity mirrors these transitions in alongshore sediment transport, with a net diffusive headland transitioning to the spit, with decreasing diffusivity up to the point where alongshore sediment transport is maximized. The shoreline downdrift of this point is unstable $\left(\mu_{\text {net }}<0\right)$, which suggests a potential tendency towards the formation of self-organized alongshore sand waves.

Previous studies (Peterson et al., 2008) have suggested that spits can only grow for waves beyond the maximum in sediment transport. Our model results agree in concept - growth only occurs for the shoreline that is past the flux-maximizing angle - but in our modeling experiments with an eroding headland, the headland and a large portion of the spit itself experience wave angles below the flux maximum. The hook grows at a rate determined by $Q_{\mathrm{s}, \max }$.

\subsection{Morphological components of a spit}

These first model results (Fig. 4) motivate a process-based framework for identifying different domains along a growing spit (Fig. 5), allowing us to define two key parts of a spit by formalizing the colloquial terms "neck" and "hook". Assuming that there is no sediment loss off of the spit end, given the free downdrift boundary condition, spits tend towards a zero flux at the downdrift end. For eroding headlands, alongshore sediment transport must increase from the nodal (zero flux) point towards the spit neck, and then pass through the maximum in alongshore sediment transport, after which sediment transport decreases towards the spit end. As such, we define the "neck" as the portion of the spit which extends from the headland to the location of maximum sediment transport, $Q_{\mathrm{s}, \max }$. The "hook" then comprises portions of the spit downdrift of the flux-maximizing location up to the spit end. As the hook is by definition beyond the maximum in $Q_{\mathrm{s}}$, it experiences a high-angle wave climate and therefore the coastline tends towards instability throughout this reach.

The updrift neck necessarily experiences divergent sediment transport, and is therefore erosive. Sediment transport converges along the hook, which is accordingly progradational. After Davis (1896) we define the "fulcrum point" as the point between the neck and the hook where $Q_{\mathrm{s}}$ is maximized and erosion transitions to accretion, and stability transitions to instability. Note that the spit shape does not itself rotate about this fulcrum point. In fact, if the wave climate remains constant, the shoreline at the location of $Q_{\mathrm{s}, \max }$ by definition maintains the same angle throughout spit growth. 


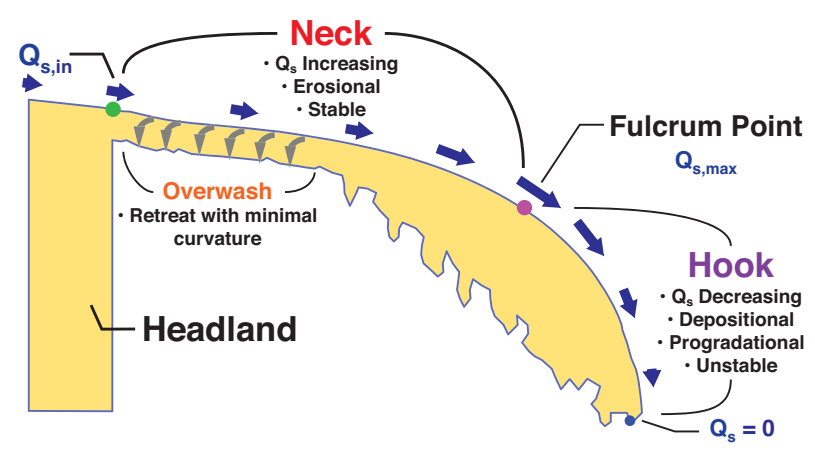

Figure 5. Schematic of key morphologic components of a spit defined using alongshore sediment transport relationships.

Basic trends of hook growth, neck erosion into preexisting deposits (i.e., beach ridge truncations), and overwashing necks are apparent in natural examples (Fig. 1). As a result of rotation of the headland coast, modeled spits eventually extend more or less straight off of the headland. Looking at the spit as the entity downdrift of the headland, we can define both the location and a quantity of net alongshore sediment that the headland supplies to the spit, $Q_{\mathrm{s}, \mathrm{in}}$. For an eroding headland, $Q_{\mathrm{s}, \text { in }}$ is necessarily less than the value of the maximum potential alongshore transport, $Q_{\mathrm{s} \text {, max }}$, and the shoreline angle at the spit origin is correspondingly less than the one which maximizes alongshore sediment transport. This last situation may not be the case for individual flying spits forming from a high-wave-angle environment (Ashton and Murray, 2006a; Ashton et al., 2007; Kaergaard and Fredsoe, 2013b), but here we focus our attention on eroding headlands. As we explore below, $Q_{\mathrm{s}, \text { in }}$ is time-varying and dependent upon not only the wave climate but also the evolution of the spit itself.

As alongshore transport gradients are the primary cause of shoreline change, coastline curvature results in either erosion (on the neck) or accretion (on the hook) depending on whether the maximum in sediment transport has been exceeded (Fig. 2). Larger curvatures should correspondingly relate to more rapid rates of erosion or progradation for the same shoreface depth. However, shoreline erosion along the neck can also be driven by overwashing of the narrow portions of the spit. In this overwashing region, the shore can transgress in the absence of alongshore sediment transport gradients driven by shoreline curvature. We again emphasize that in the model experiments here we simplify the influence of overwash by assuming that the backbarrier region is the same depth as the shoreface. If the backbarrier were shallower, then the overwashing portion of the coast would also be expected to be curved.

\subsection{Headland controls on spit form}

In the next set of model experiments, we vary headland width between model runs. We choose a symmetrical wave climate to make comparisons between different cases more exact and to limit the spin-up behaviors caused by relaxation from the initial conditions. The choice of an exactly symmetrical wave climate does not necessarily limit the application of these experiments, as we have already demonstrated that spits growing from an asymmetrical wave climate eventually develop similar fluxes off of both sides (Fig. 4).

As would be naïvely expected, narrower headlands erode faster than wider ones. For the same rate of sediment export to the spit, wider headlands would be expected to recede at a slower rate as they have longer shoreline length to provide sediment to the spit. The more rapid erosion rate of the narrower headland corresponds to greater gradients in sediment transport along its length (Fig. 6; also see movies in the Supplement). Perhaps less expected, however, are the clear differences in spit shape, neck orientation, neck length, and hook curvature. As these spits are formed from the same wave angle climate, these differences arise solely due to differences in headland width.

The morphologic differences between the spits can be visualized in a number of manners, either from the perspective of the model domain or comparatively (Fig. 7). Aligning the updrift shore locations (Fig. 7b) shows a series of spits with visually different shapes and, most importantly, orientations, even as all of these spits grew from the same wave conditions. As such, correlating spit shape and orientation with (paleo-)environmental driving conditions may be considerably more complex than has previously been assumed.

The mechanisms for these differences in spit shape can be better understood by examining the time evolution of different variables and geometric characteristics of the modeled spits (Fig. 8). The neck angle (angle between the locations of $Q_{\text {s,in }}$ and $Q_{\mathrm{s}, \max }$, Fig. 5) decreases over time for all cases, with smaller angles developing for narrower headlands. The sediment flux into the spit itself, $Q_{\mathrm{s} \text {,in }}$, also decreases over time, again with narrower headlands delivering less sediment. The reduction of sediment input over time highlights important feedbacks between spit extension and the headland itself - as a narrow headland is quickly eroding, it in turn reduces the rate of sediment loss of the headland (and the rate of spit mass growth) by reducing the shoreline angle at the spit entrance. Over time, the neck angle and $Q_{\mathrm{s} \text {,in }}$ tend towards a steady state as the spit grows (Fig. 8). Because of this reduction of sediment export from the headland, the rate of erosion of narrower headlands reduces as the headland-spit system develops, but not enough to slow a narrow headland to the same rate as a wider one.

For all cases, the shoreline arc length (i.e., wave-facing perimeter) of the neck continues to grow as the fulcrum point (location of $Q_{\mathrm{s}, \max }$ ) migrates and the spit extends (Fig. 8c). Faster eroding headlands grow longer-necked spits, which is perhaps unexpected as thinner headlands develop smaller $Q_{\mathrm{s} \text {,in }}$ than wider ones. Hook arc length is larger for wider headlands (Fig. 8d). This suggests that hook length is an emergent variable that arises from feedbacks between the 

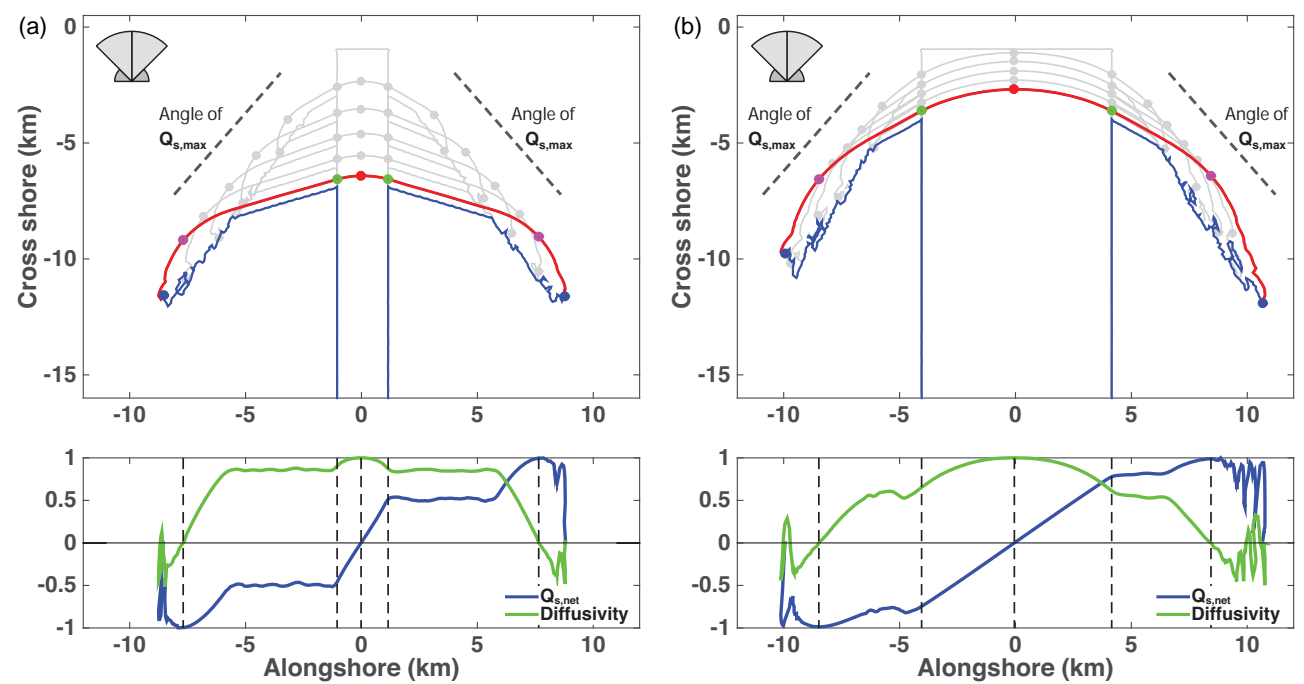

Figure 6. Spit growth with symmetrical (and identical) wave climates, but with different initial headland widths of (a) $2 \mathrm{~km}$ and (b) $8 \mathrm{~km}$, after 96 model years with corresponding plots of normalized alongshore sediment transport and diffusivity $(A=0.5, U=0.1)$.
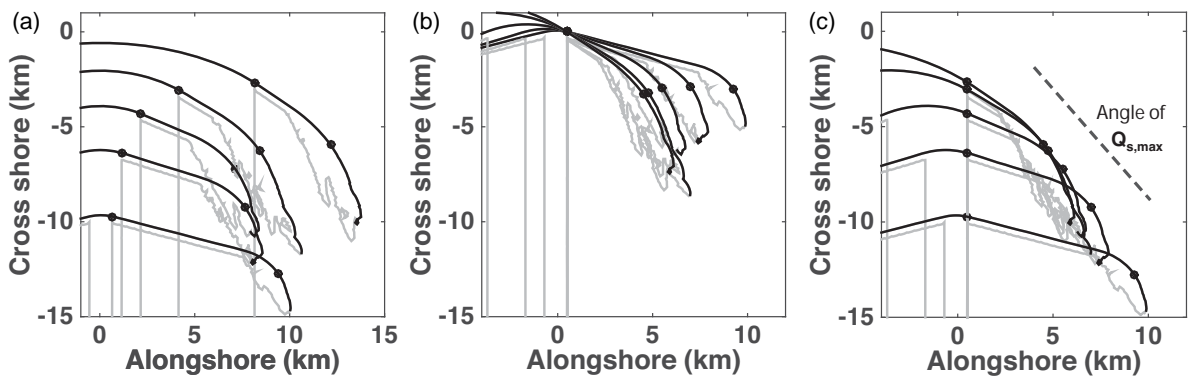

Figure 7. Different visualizations of symmetric spits growing off of different headland widths after 220 model years plotted (a) in "modeler's view" symmetrically about the headland where $x=0$ is location of the initial headland, (b) in "geologists view" with same location of spit origin after evolution (i.e., same $Q_{\mathrm{s} \text {,in }}$ location in $x$ direction), and (c) with the same right headland boundaries where $x=0$ is the location of the initial headland. Also plotted is the trajectory of the angle at which alongshore sediment transport is maximized for the wave climate. Note that wave climate is the same for all simulations $(A=0.5, U=0.2)$.

headland recession rate, the wave climate, and sediment input rates. For a given wave climate, the amount of sediment a hook receives is set by $Q_{\mathrm{s}, \max }$. Spreading this sediment across a smaller hook arc length results in faster progradation, providing a mechanism for hooks to extend more rapidly for narrower (faster eroding) headlands. Note that the hook length tends to fluctuate more than the other variables (Fig. 8d). These fluctuations are mostly because selforganized sand wave features begin to develop along the hooks, where the shoreline is unstable and accreting.

The interplay and feedbacks between spit components that result in different hook arc length and migration rate can be further understood by examining the trajectories and onshore movement of the key spit components. Plotting spits from a common initial location (Fig. 7c) demonstrates that the fulcrum point takes approximately the same onshore trajectory - the angle at which sediment transport is maximized - irrespective of the headland width. Over time, the onshore ve- locities of the headland nodal point, spit origin (location of $Q_{\text {s,in }}$ ), and the fulcrum point decay towards time-constant values (Fig. 9). All components of the narrower headland spit move landwards faster than those with a wider headland.

Together, the fixed trajectory of the fulcrum point and the onshore velocities of the key spit components explain how thinner headlands extend spits more rapidly: as the rapid headland erosion drives the overwashing shore landwards, the fulcrum point must also travel more rapidly (Fig. 9) along the trajectory determined by the wave climate (Fig. 7c). The arc length of the hook adjusts to attain a steady state with the rate of migration of the fulcrum point, and smaller arc length leads to more rapid progradation (Fig. 8d). In part, this more rapid landward erosion of the headland is buffered by the reduction of sediment transport to the spit itself (Fig. 8b), which in turn reduces headland erosion rate. Note also that differences in the rate of sediment input can also be observed in the plan-view areal extent of the spits themselves (Fig. 7). 

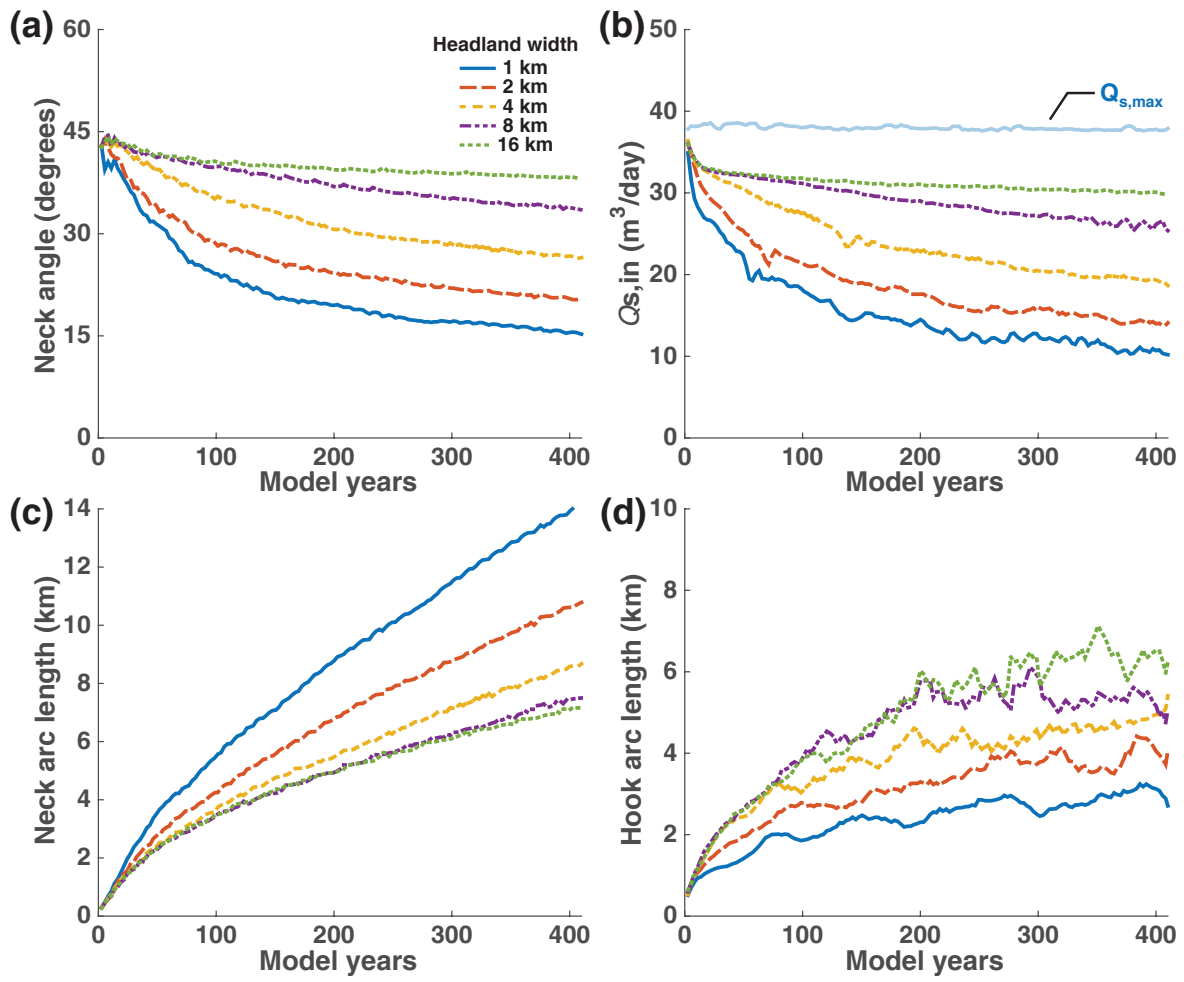

Figure 8. Characteristics of spits growing from a symmetrical wave climate $(A=0.5, U=0.2)$ with different initial widths, showing change in time of (a) the neck angle (defined as the line from the locations of $Q_{\mathrm{s}, \text { in }}$ to $Q_{\mathrm{s}, \mathrm{max}}$ ), (b) the alongshore flux into the spit at $Q_{\mathrm{s}, \text { in }}$, (c) neck arc length, and (d) hook arc length.
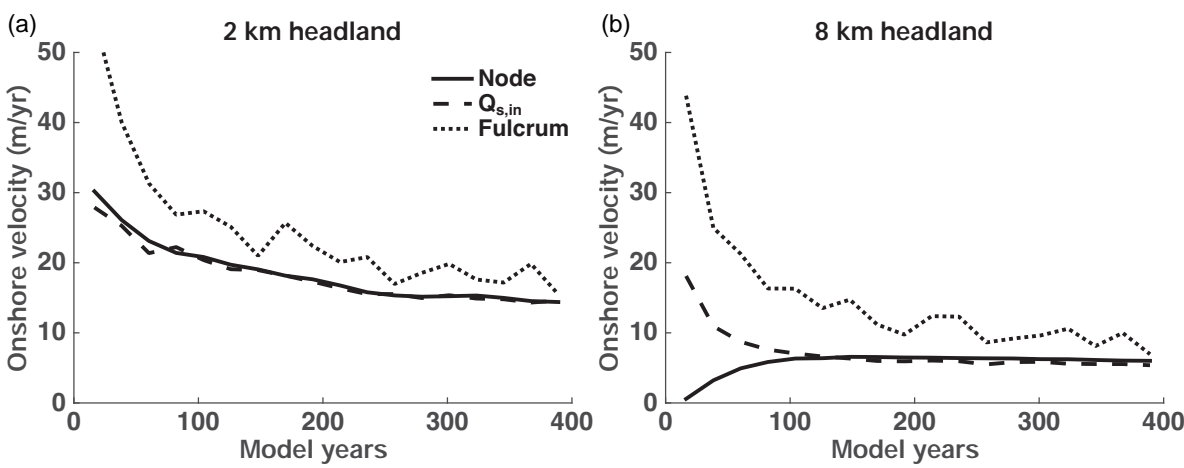

Figure 9. Rates of onshore migration of key spit locations over time for headlands of initial width of (a) $2 \mathrm{~km}$ and (b) $8 \mathrm{~km}$, both experiencing symmetric wave climates $(A=0.5, U=0.2)$.

Other dynamics can be observed in the onshore velocity trends (Fig. 9). First, wider spits show a substantial delay before the node attains the same velocity as the entrance to the spit (Fig. 9) due to spin-up from the artificial initial conditions. Perhaps more interesting, while a seeming steady state has developed after several hundred model years, the fulcrum point still maintains a faster onshore velocity than the headland. Even though spit dynamics have slowed down considerably, these freely evolving spit features have not yet attained a true steady state and spit orientation (i.e., neck angle) continues to change, albeit slowly (Fig. 8a).

An alternative way to conceptualize the phenomenon of more rapid headland erosion driving faster spit extension is by considering the difference between $Q_{\mathrm{s} \text {,in }}$ and $Q_{\mathrm{s}, \max }$. The value of $Q_{\mathrm{s} \text {,max }}$ is set by the wave climate, independent of spit dynamics (although this value can be slightly reduced if the spit is shadowed by the headland itself). The maximizing flux must occur somewhere along a spit (Fig. 5). A narrower, faster eroding headland reduces the shoreline an- 

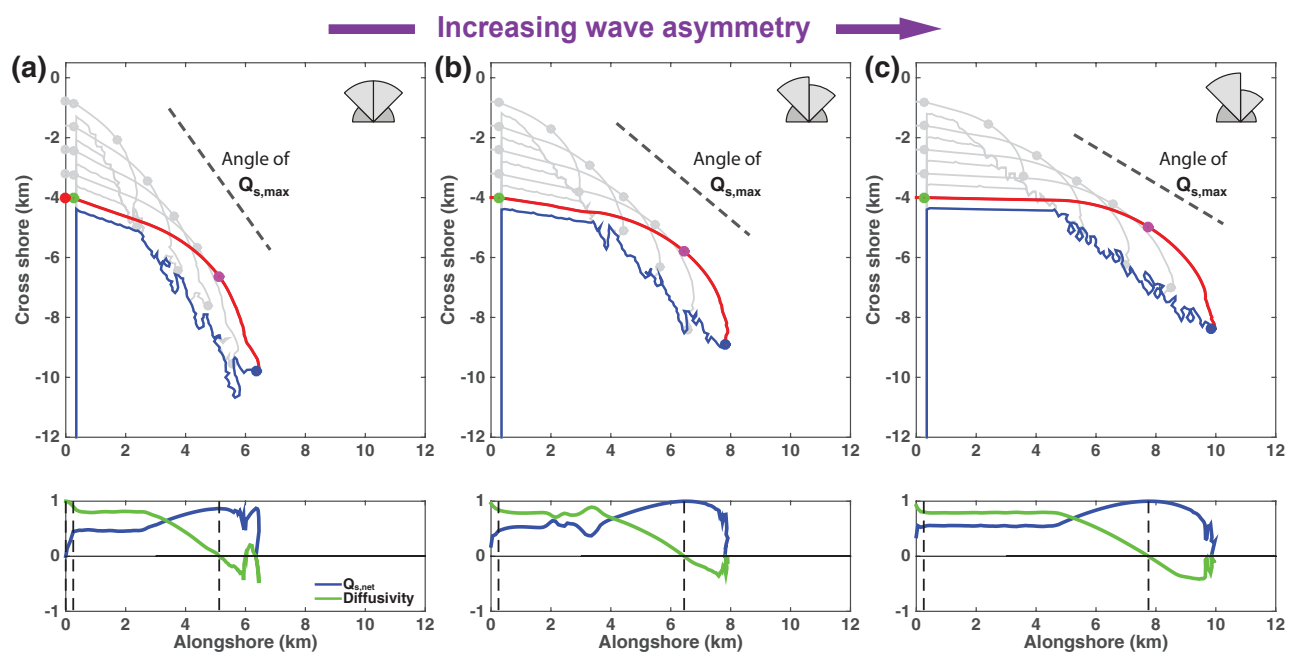

Figure 10. Plan views of modeled spits extending off of a headland eroding at a fixed rate of $0.08 \mathrm{~m} \mathrm{day}^{-1}$ after 137 model years (with "ghost" shorelines every 27 model years) above plots of normalized sediment transport and diffusivity. The only difference between simulations is the wave asymmetry: (a) $A=0.5$, (b) $A=0.6$, and (c) $A=0.7(U=0.2)$. Plot features explained further in Fig. 4 caption.

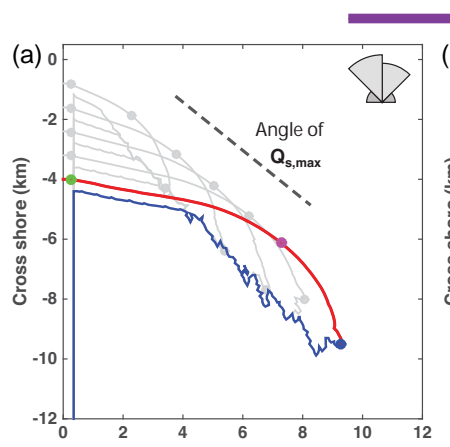

Increasing wave spread
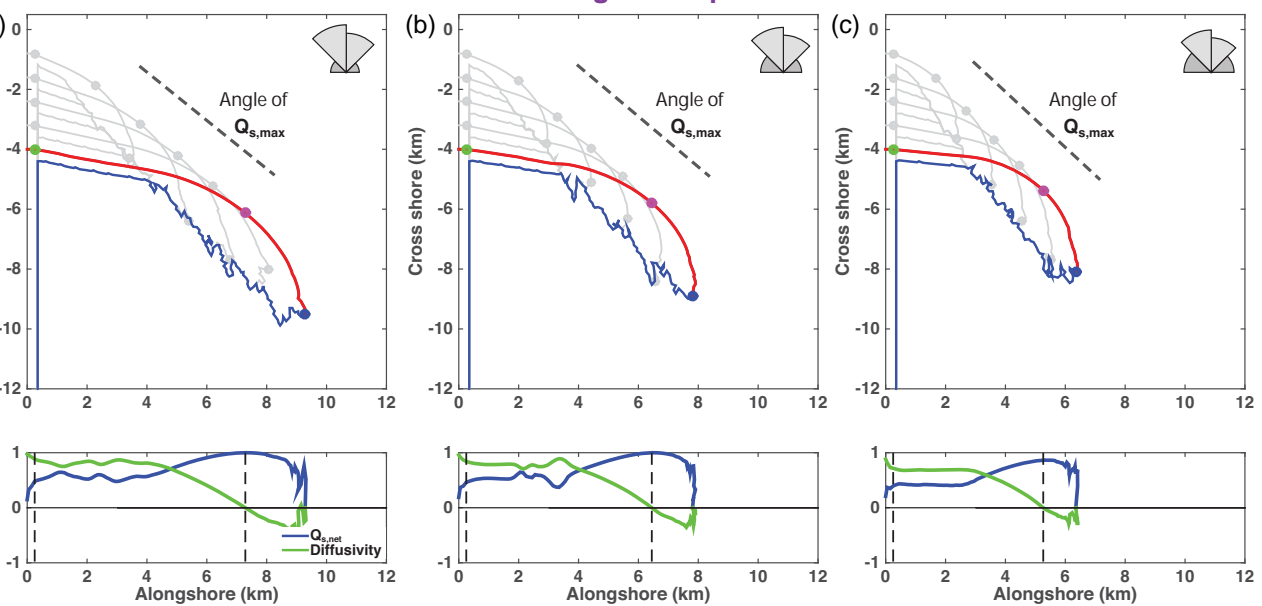

Figure 11. Plan views of modeled spits extending off of a headland eroding at a fixed rate of 0.08 m day $^{-1}$ after 137 model years. The only difference between simulations is the wave spread: (a) $U=0.1$, (b) $U=0.2$, and (c) $U=0.3(A=0.6)$. Plot features explained further in Fig. 4 caption.

gle at the spit origin, thereby reducing $Q_{\mathrm{s}, \text { in }}$ compared to a wider, slowly eroding headland. In the cases presented here, because the backbarrier and shoreface depths are equal, overwashing does not add mass to the spit system. Consequently, the deficit between $Q_{\mathrm{s} \text {,in }}$ and $Q_{\mathrm{s} \text {, } \max }$ must be accommodated by eroding into the spit shoreline itself. The flux deficit is made up by sediment eroded between the neck location where overwashing ends and the fulcrum point. A larger sediment deficit results in a larger rate of erosion of this distal part of the neck, which, in turn, drives more rapid migration of the fulcrum point along the trajectory set by the angle that maximizes alongshore sediment transport. The hook itself accommodates this faster rate of migration of its upper boundary by attaining a shorter length (with sharper curvature).

\section{Systematic analysis of controls on spit form}

The intertwined feedbacks between a spit's headland, neck, and hook confound attempts to isolate the influence of any one characteristic or driving force on spit evolution, particularly when there is an asymmetry in the wave climate (Fig. 4). In the experiments shown above for a freely eroding lowlying headland, significant portions of the model experiment (and spit growth itself) involve the decay of the initial conditions; this decay is more prominent for larger-width head- 

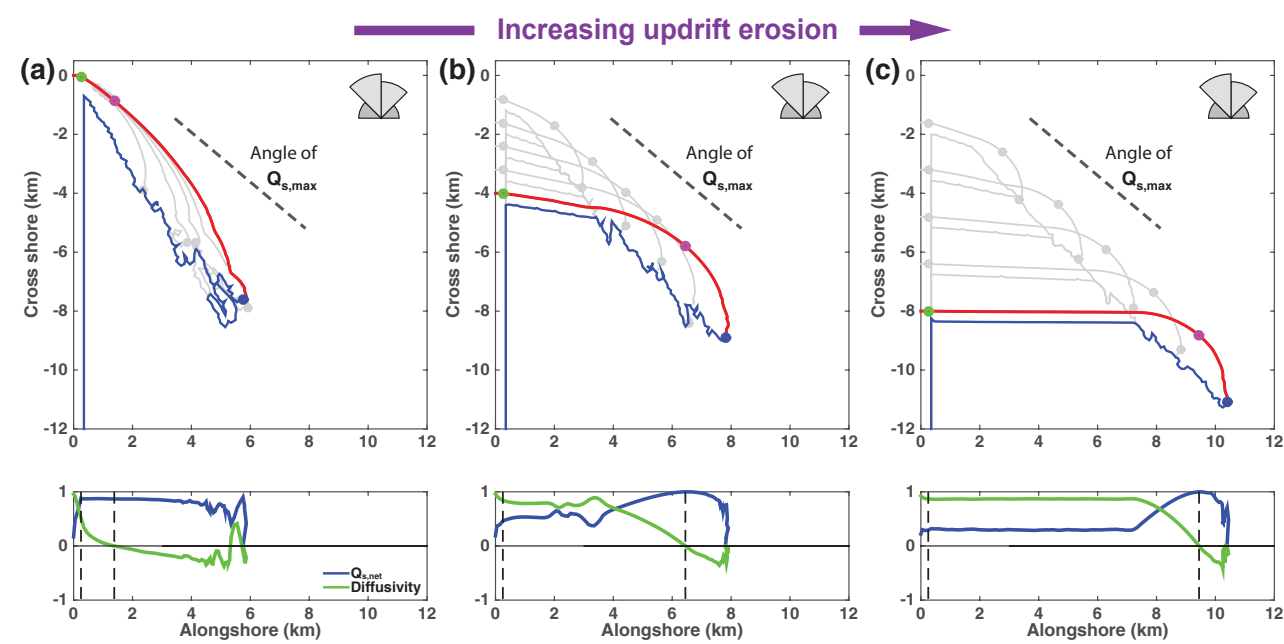

Figure 12. Plan views of modeled spits extending off of a headland eroding at a fixed rate after 137 model years. The only difference between simulations is the rate of imposed headland erosion: (a) $F=0$, (b) $F=0.08 \mathrm{~m} \mathrm{day}^{-1}$, and (c) $F=0.016 \mathrm{~m} \mathrm{day}^{-1}(A=0.6, U=0.2)$. Plot features explained further in Fig. 4 caption.

lands, which makes it difficult to directly assess the effect of headland erosion rate on spit form (e.g. Fig. 9). Furthermore, in natural cases, headlands often have varying elevations where cliffs and/or bluffs may provide the sediment supplied to spits. As these headlands are typically geologic relicts, they may consist of both beach-compatible sand and fine-grained sediment and perhaps lithified rock that would result in different rates of headland erosion for a given rate of removal of sediment by the littoral transport system (Limber and Murray, 2011; Valvo et al., 2006).

In the numerical experiments detailed above for a freely eroding headland, the rate of headland erosion eventually tends towards a constant rate. Motivated by this trend towards a steady state, here we present a series of experiments where, instead of allowing a "free" headland to erode, the updrift coast moves landward at a constant, set rate. By holding updrift erosion constant, we then can, in a controlled manner, investigate spit evolution for different wave climates (Figs. 10, 11), rates of headland erosion (Fig. 12), and basin depths (Fig. 13).

Another potential approach for controlled experiments would be setting a fixed sediment influx (Petersen et al., 2008). However, our previous results demonstrate that flux onto a spit is set by the shoreline orientation at the updrift spit limit - this updrift shoreline orientation itself arises from feedbacks between the spit components. As the rate of sediment input changes over time (Fig. 8), an arbitrary constantflux updrift condition does not seem to be appropriate for our case of spits growing off of a headland. Therefore, for our model experiments the updrift boundary flux condition is open (set at each time step based upon the local shoreline orientation compared to the wave climate).

\subsection{Wave climate controls}

We isolate the two potential wave-climate-related controls on spit shape, the asymmetry $(A)$ and the breadth of the wave climate $(U)$. A larger value of $A$ corresponds to a larger rightgoing net littoral drift for a straight coast. As wave climates become more asymmetrical (Fig. 10), modeled spits orient themselves with necks rotating towards the direction of approaching waves (Fig. 14a), similar to the results for freely eroding headlands in an asymmetric wave climate (Fig. 4). Increasing asymmetry results in slightly larger $Q_{\mathrm{s} \text {,in }}$, which corresponds to slightly faster rates of spit extension, although hook perimeters remain similar (Fig. 14a).

Increasing the breadth of approaching waves, by increasing $U$, results in an overall less diffusive wave climate. Larger wave spread has a somewhat subtle effect on spit shape. Waves approaching from a broader swath of angles reduce the net sediment transport for all cases, and $Q_{\mathrm{s} \text {,in }}$ is reduced as $U$ increases. For larger $U$, the spit hook is more sharply curved, in part because the hook faces more waves overall when the distribution is broader. As the angle of maximum sediment transport is little affected by $U$, neck angles do not change.

\subsection{Headland erosion controls}

As suggested by the experiments with freely eroding headlands, the rate of updrift erosion has a clear and perhaps overwhelming influence on spit form (Fig. 12). Rapidly eroding headlands drive fast migration of the spit hook, and a long overwashing neck develops with a corresponding small hook with large curvature (Fig. 12c). In this case, most of the spit shoreline is erosive, mainly through transgressive overwashing. The rapid erosion leads to a shallow neck angle, which 


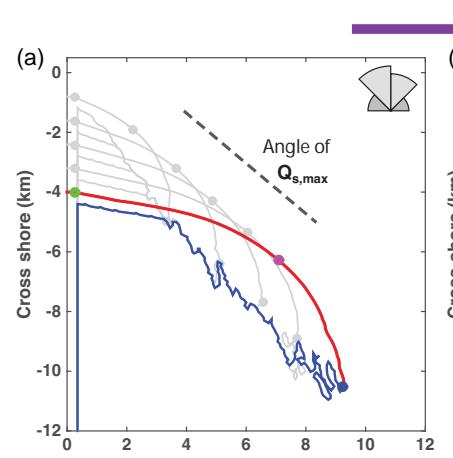

Increasing shoreface depth
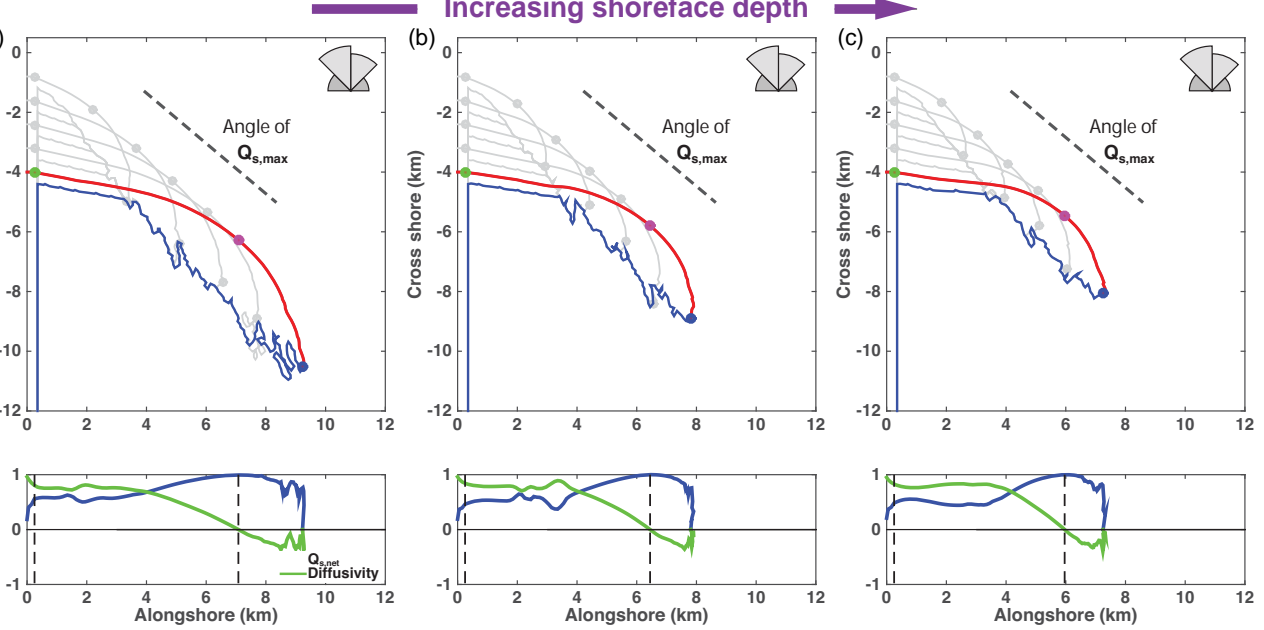

Figure 13. Plan views of modeled spits extending off of a headland eroding at a fixed rate of $0.08 \mathrm{~m} \mathrm{day}^{-1}$ after 137 model years. The only difference between simulations is the shoreface depth and concomitant basin depth: (a) $D=10 \mathrm{~m}$, (b) $D=15 \mathrm{~m}$, and (c) $D=20 \mathrm{~m}$ ( $A=0.6, U=0.2$ ). Plot features explained further in Fig. 4 caption.

reduces sediment input significantly (Fig. 14c). This again leads to the perhaps counterintuitive result that a decreased rate of sediment input can accompany more rapid spit extension.

On the other hand, a fixed headland results in a spit that is essentially all hook (Fig. 12). As the maximum in sediment transport is exceeded near the headland, the spit itself is almost entirely depositional. The elongate hook has little curvature, resulting in a long shoreline with small gradients in alongshore transport and a tendency to instability throughout. Sand waves and secondary spits self-organize off the downdrift tip, resulting in more irregular shorelines and fluctuations of the hook length (Fig. 14c). The development of an entirely depositional spit bears a similarity to previous modeling results with a fixed headland (Kaergaard and Fredsoe, 2013a; Petersen et al., 2008), and the fixed headland case is the only one where $Q_{\mathrm{s} \text {,in }}$ remains constant during spit growth. This case is an illustrative example that might not be realized often in nature as it assumes a fixed headland, and therefore probably a rocky shore, yet a full supply of sediment. However, a possible example could be at the mouth of a delta where a river supplies sediment to the littoral system (Giosan et al., 2005).

\subsection{Basin depth controls}

For the last set of experiments with a forced updrift boundary, we vary the depth of the depositional basin, including the shoreface depth and backbarrier depth. The naïve expectation for such an experiment would likely be that, given the role of depth in the cross-shore mass balance, spits extending into a basin twice as deep should do so at half the rate. Model results, however, suggest that although progradation into deeper basins is slower than for shallower ones, the re- duction in neck growth rate is relatively small (Fig. 13). Instead, modeled spits growing into deeper basins have substantially smaller hook lengths (Fig. 14d) and consequently smaller areal extent.

This influence of basin depth can be understood using principles from the other experiments - headland erosion drives the location of the fulcrum point on- and alongshore, again with the trajectory determined by the wave climate. The spits have similar orientations, and the rate of input of sediment onto the spit is the same for all cases as it is determined by the alongshore sediment flux which, to first order, is not affected by the basin depth. However, in a deeper basin, mass conservation requires a shorter shoreline arc length (with corresponding larger curvature) to cause the same gradient of alongshore sediment transport (the difference between $Q_{\mathrm{s}, \max }$ and 0 at the spit end) to prograde the hook at the same rate as in a shallower basin (Fig. 14d).

Note that this last case of changing basin depths is perhaps not realistic as, for a free headland, the depth of the shoreface may not necessarily be the same as that of the depositional basin. More intricate behaviors could be expected as a shallower shoreface erodes into deeper deposits. Compared to our one-contour-line model, a more explicit mass balance approach might refine these results (e.g., Kaergaard and Fredsoe, 2013a). However, our exploratory model results suggest that the first-order effect of a deep depositional basin may not be slowing of spit growth but rather a decrease in hook length. 
(a)

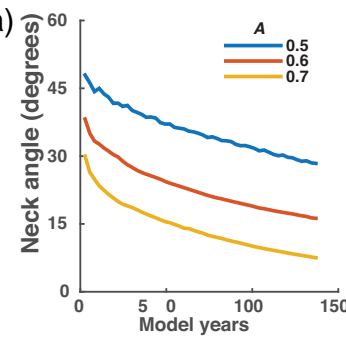

(b)

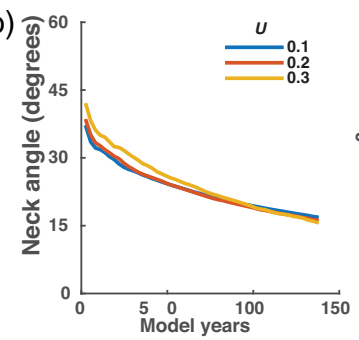

(c)

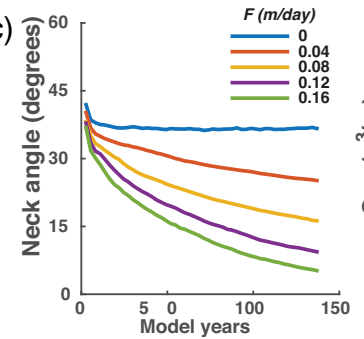

(d)

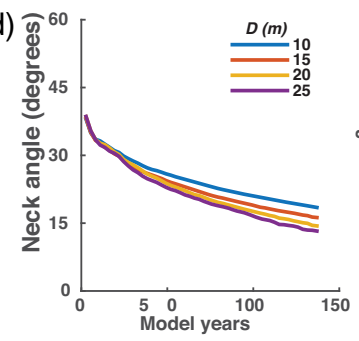

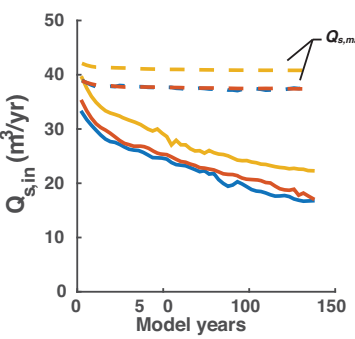
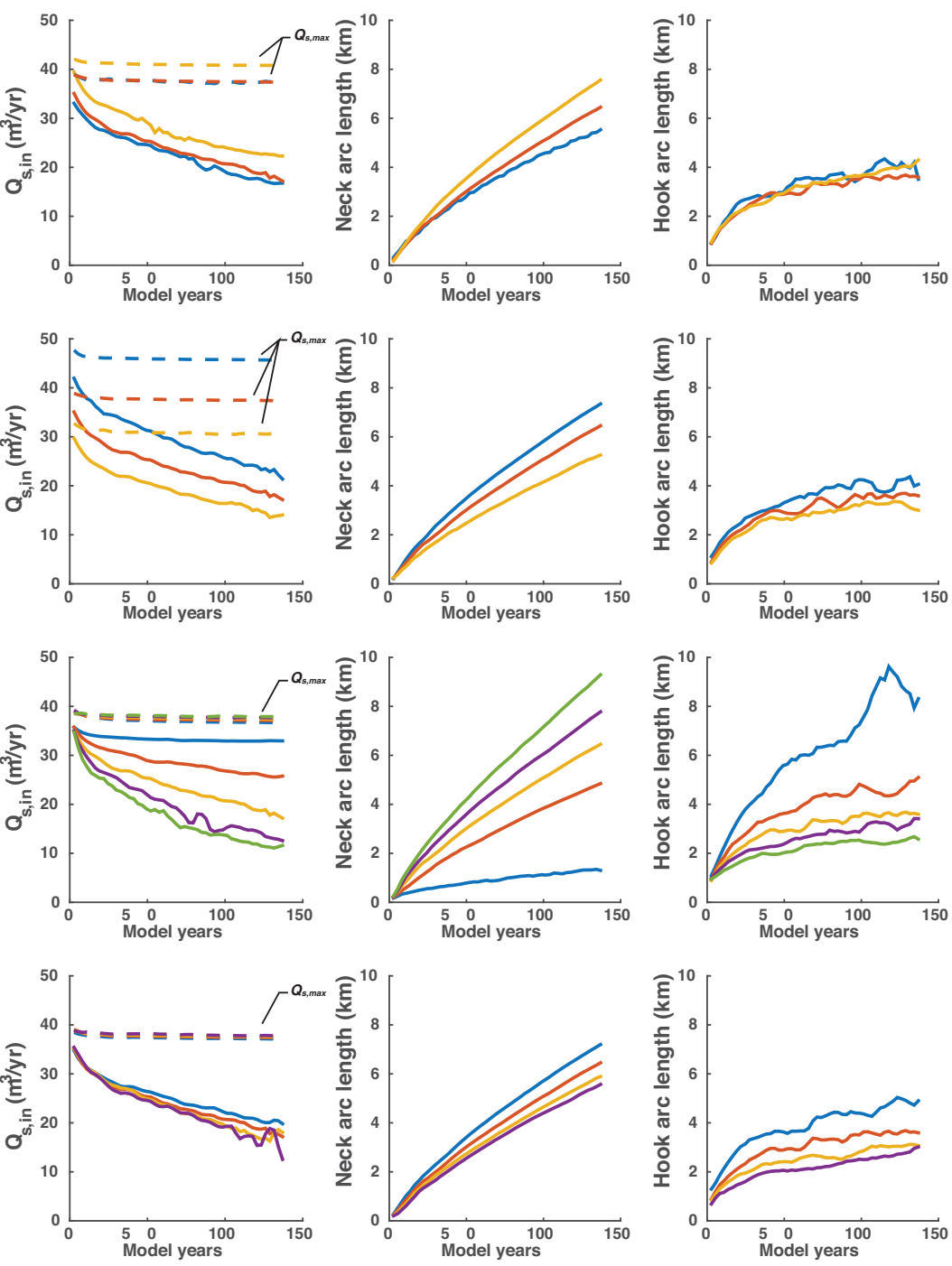

Figure 14. Spit characteristics over time for simulations with imposed rate of updrift retreat (shown in Figs. 10-13), reflecting the effect of changes in (a) wave asymmetry, (b) wave spread, (c) rate of forced retreat, and (d) shoreface/basin depth. Default run parameters are $A=0.6, U=0.2, F=0.08 \mathrm{mday}^{-1}$, and $D=15 \mathrm{~m}$.

\section{Discussion}

\subsection{Dynamics of spit-headland systems}

The results presented here suggest that the complex interconnected dynamics of spit-headland systems could easily be overlooked if an analysis only focuses on one aspect of the spit itself. For example, the rate of sediment input to the spit itself is determined by feedbacks between the spit and the upcoast shore even as the maximum potential sediment transport is set by the wave climate. The difference between this sediment input and the maximum alongshore sediment transport creates a sediment deficit in the neck, which is, in the case where overwash does not passively provide additional sediment, accommodated through shoreline orientation changes before the fulcrum point. This neck erosion then drives the fulcrum point downcoast. The trajectory of the fulcrum point is set by the angle of maximum transport and its rate of motion is determined by the sediment imbalance on the spit neck.

The accreting hook coast downdrift of the fulcrum point attains a graded shape such that progradation is equal alongshore. If the fulcrum point is driven downcoast at a more rapid pace (due to the sediment deficit), then the spit hook must be shorter and more sharply curved to prograde at a faster rate for what is a fixed rate of sediment input (by definition $Q_{\mathrm{s}, \max }$, determined by the wave climate). Similarly, if the hook is prograding into deeper water, a sharper curvature is needed for it to extend at the same rate because the same flux of sediment into the hook, $Q_{\mathrm{s}, \max }$, must be spread over a greater effective depth. Note that because the hook curvature 
is variable and responsive to updrift forcing conditions, the rate of progradation of a spit does not necessarily increase for an increased sediment input to the spit itself. Instead, often the opposite is true and rapid spit progradation accompanies reduced sediment input.

Why does the angle of maximum sediment transport set the fulcrum point trajectory? As the spits tend towards steady state, the gradient in $Q_{\text {s,net }}$ becomes constant along the recurved hook (Figs. 4, 6). In this graded state, erosion and deposition are balanced on either side of the fulcrum point. Regardless of the rate of erosion/deposition (i.e., slope of $Q_{\text {s,net }}$ ), because the fulcrum point is defined as the shoreline angle where $Q_{\text {s,net }}$ is maximized, this point translates downcoast at this flux-maximizing angle. However, outside of steady state (or a condition near it), erosion and deposition may not be exactly graded passing through the fulcrum point, which could result in a different trajectory. Such transient behavior can be seen in initial stages of spit development (Fig. 9) and would be expected for changes in environmental setting (for example a non-rectangular headland or a spit growing into a shoaling basin).

\subsection{Hook instability}

We define the morphodynamic hook as the shoreline that is past the maximum in alongshore sediment transport; as a consequence, this shoreline should be unstable to perturbations because of the high-angle wave instability. The propensity for spit ends to tend towards instability has been previously proposed for oblique wave incidence (Ashton and Murray, 2006b) and shore-normal incidence (Ashton et al., 2007). Shoreline sand waves and other organized shoreline undulations can be found on the ends of many spits (DavidsonArnott and Van Heyningen, 2003; Medellín et al., 2008). All but one of the sample spit shorelines we selected show shoreline undulations, either subtle (Fig. 1e, f, g) or prominent (Fig. 1b, c) along the hook, occurring across a range of spatial scales (note that some features are too small to be visible at the scale of Fig. 1).

The CEM, with its simplistic wave refraction treatment, tends to form shoreline sand waves at the model's discretization scale. These modeled sand waves tend to develop most prominently along longer, straighter hook shorelines, and are absent on shorter hooks with larger curvature. As these short hooks are rapidly prograding, it is likely that large gradients in alongshore sediment transport overwhelm smaller instability-driven gradients and the shoreline remains smooth.

Theoretically, shoreline sand waves are expected to occur throughout the hook; however, their prominence along a natural spit depends on several factors. Foremost, other recent research, using more complex wave transformation approaches, has shown that the tendency towards shoreline instability emerging from an initially straight shoreline may not manifest in the growth of perturbations at spatial scales smaller than hundreds of meters to kilometers (Falqués and Calvete, 2005; Falqués et al., 2011; López-Ruiz et al., 2014). Therefore, in nature, shoreline sand waves may not be prominent on short spit hooks for the following reasons: (1) such short hooks are often prograding rapidly such that the gross gradients in alongshore sediment transport may dominate shoreline change; (2) these hooks may be of insufficient length for kilometer-scale sand waves to initially develop; and (3) also because of this limited coastal extent, small-scale sand waves could migrate to the spit end before becoming large. In contrast, long gently curving hooks (such as those found for slowly eroding headlands) have long stretches of coast exposed to high-angle waves. Emergence of autogenic shoreline features such as sand waves and, in some cases, flying spits adds to the variability in the hook length in this case.

Additionally, López-Ruiz et al. (2012) recently demonstrated that the shoreline curvature itself might also lead to the growth of a single perturbation on a spit end, particularly when shoreline contours are non-shore-parallel. These single shoreline undulations, also observed by Bruun (1954), offer another mechanism for formation of finite-amplitude undulations within the hook region upon which further shoreline instability can act. Individual undulations in high-angle environments can both propagate and potentially spawn other features (van den Berg et al., 2011, 2012) and the presence of high-angle instability could then reshape and reinforce perturbations on the hook coast.

Overall, as the depositional hook is unstable, the potential for self-organized shoreline behavior exists. For all spits, deposition coincides with the potential for shoreline instability - the part of the spit that records stratigraphy is exactly the region where autogenic signals are likely to develop. This has strong implications for interpretations of depositional signals for all recurved spit environments, as periodicity or episodicity in depositional signals may not be representative of changes in forcing regimes over short or long time periods and may instead be autogenic. Therefore care should be taken in interpretations of spit growth signals (e.g., Allard et al., 2008).

\subsection{Effect of wave angle approach change}

As wave climate, and in particular wave climate asymmetry, affects spit shape (Fig. 10) and, more importantly, trajectory (Fig. 14a), changes in the distribution of approaching waves should be expected to affect spit growth as it would along other coastlines. Preliminary model results (Fig. 15) demonstrate the sensitivity of prograding spits to slight changes in wave approach angle. A small $(10 \%)$ change in the wave angle distribution moves the fulcrum point and, correspondingly, moves the transition between the erosional neck and the accretionary hook. Such a change, potentially due to long-term climate oscillations, can result in altered patterns of progradation and beach ridge truncation. 

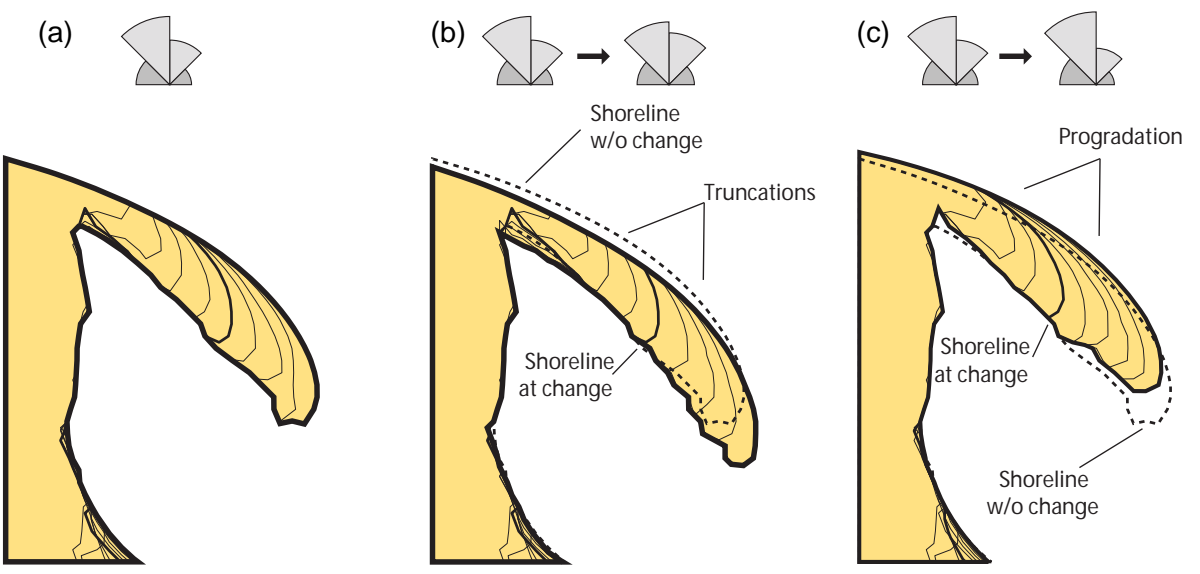

Figure 15. Model simulation of spit undergoing a $10 \%$ change in wave direction and directional spread climate during growth. (a) No change in wave climate $(A=0.7 U=0.2)$, (b) wave direction shifts to the right $(A=0.6 U=0.1)$, and (c) wave direction shifts to the left $(A=0.8 U=0.3)$.

\subsection{Multiple wave approach directions}

An important aspect of the modeling results presented here is the use of multiple wave approach angles, which is the common case for naturally occurring spits. It has been pointed out that, as a result of wave refraction simplifications, a model such as CEM cannot accurately model spit growth from waves approaching from only one direction (Kaergaard and Fredsoe, 2013a; Petersen et al., 2008). However, such an exact case (waves approaching from only one angle with no directional spread) is uncommon in nature. In the results here, well-rounded spit shapes form robustly as a result of varying wave approach angle, and the distribution of waves itself demonstrably affects the growth and shaping of spit hooks (Fig. 12).

Spits are reshaped by waves even as they grow from sediment input. Over the growth and shaping of a spit, a distribution of wave approach angles should also be important because waves that contribute significantly to sediment flux and therefore spit growth (angles near $45^{\circ}$, Fig. 2b) have an almost inconsequential role in reshaping the shoreline (Fig. 2c). Correspondingly, the waves that most strongly reshape the shoreline (angles near 0 or $90^{\circ}$ ) with large angledependent flux gradients contribute smaller fluxes and therefore contribute little to spit growth. Also, as seen in the results here, by using multiple angles, a spit end can experience waves that would otherwise be shadowed by other parts of the spit, allowing the shoreline to curve more than if a single wave approach angle is used. This would suggest that a common modeling approach of using only waves from one direction (or small variations around a mean angle) is likely fraught with as many concerns as the simplifications used in our approach. Qualitatively, the results presented here show that a moving headland and a wave climate comprised of many angles play significant roles in determining hook curvature.

\subsection{Model limitations}

The phenomenological behavior of the coupled spitheadland system arising from the model results presented here follows from basic principles of shoreline evolution. As discussed above, the CEM contains several simplifications that may affect the specifics of model application. The model uses a simple refraction treatment, which may affect the details of results at sharply curving coasts. Also, the model tends towards the formation of self-organized sand waves on the hook at scales based upon the domain discretization. Furthermore, the model assumes the shoreline represents a prismatic section of the shoreface, an assumption that deteriorates when significant shoreline curvature exists at the scale of the shoreface itself. As demonstrated by Kaergaard and Fredsoe (2013b), shoreline curvature can also affect the shoreline orientation at which $Q_{\mathrm{s}, \max }$ occurs by up to $\sim 10^{\circ}$; although this would not have a qualitative effect on the interactions between spit components, this would quantitatively affect the orientation of spit growth and therefore could affect the fluxes onto the spit itself.

The modeled spits have free ends, which does not include the cases where a spit end is mechanistically connected to a downdrift coast, such as when there are inlets (Hoan et al., 2011). Also, for the model experiments we assume that sediment delivered to the spit end remains in the littoral system. In many cases the terminal ends of spits are affected by strong tidal flows, which can often serve as an offshore conduit whereby sediment delivered to the spit end is delivered offshore to a subaqueous shoal.

In keeping with the one-line approach to shoreline change, we use a "morphokinematic" approach to overwash, assuming that this process is relatively instantaneous and that there are no feedbacks with the deeper shoreface. We also assume that overwash fluxes are sufficient to keep the neck spit intact. Extremely large or low overwash fluxes could 
result in barrier failure and disconnection of the spit itself (Lorenzo-Trueba and Ashton, 2014). As overwash does not widen the barrier, the only mechanism to increase barrier width is through (positive) alongshore transport gradients. Accordingly, failure is more likely to occur for cases where the spit coast is only moderately diffusional, meaning that alongshore sediment transport gradients have a harder time communicating headland erosion rates across the spit without overwash taking over. Such neck failures do appear to occur in natural examples, and disconnecting the hook from the spit itself provides a mechanism for barrier island formation even in the absence of large tidal flows.

Given the exploratory approach, the results presented here could be wrong in specific details, but unlikely egregiously so. Our results motivate a holistic approach to understanding spit form and we present a unifying framework to connect process with spit form and evolution. Most important is that the entire system needs to be considered. Future research directions include direct application to natural examples using wave climate analysis (Ashton and Murray, 2006b). The research also motivates comparisons to other modeling approaches, for example examination of the effect of shoreline curvature on the angle of maximum sediment transport, and thereby the trajectory of the fulcrum point, as examined by Kaergaard and Fredsoe (2013b).

\section{Conclusions}

Through a series of numerical experiments using a one-line coastal evolution model, we have explored key dynamics affecting the formation and shape of littoral spits. Foremost, we have used the model results to establish a process-based conceptual model of spit mechanics. Two key process domains exist along a spit that are based on changes in alongshore sediment transport: the eroding neck and the accreting hook. These two domains are separated by a fulcrum point corresponding to a maximum in alongshore sediment transport (Fig. 5). This fulcrum point migrates along a constant angle set by the wave climate. The neck can transgress both through overwash along its upper portions and, downdrift, through gradients in alongshore sediment transport as it increases towards its maximum value. Along the hook, alongshore sediment transport decreases from maximum value to zero, causing the hook shoreline to accrete with a generally graded shape. The hook arc length responds to the rate of migration of the neck-hook transition point. Throughout its length, the shoreline along the accreting hook tends towards instability.

The angular distribution of incoming waves affects spit shape, such that patterns of spit growth and erosion can be sensitive to long-term changes in wave climate. We find, however, that the most important control on spit shape appears to be the dynamics of the updrift connection to the mainland. Feedbacks between the spit end, migrating with a trajectory determined by the wave climate, and the eroding headland affect the input of sediment to the hook itself. By affecting updrift recession, the headland controls the difference between sediment input and the maximum in alongshore sediment transport (set by the wave climate). Thus, a faster eroding headland drives rapid spit extension even as it limits the rate of sediment input to the spit itself. The spit must cannibalize itself through erosion of the nonoverwashing portion of the neck, and the neck-hook transition migrates faster in response.

The results presented here provide an initial template for a more generalized process-based description of spit morphodynamics, emphasizing not only the role of wave angle climate but also the importance of geologic factors with regard to the connected headland coast. Overall, although spits may appear to be a messenger in disguise, unraveling the influence of geology and climate recorded in spit growth appears to be more complex than previously considered. The theoretical results presented here can be further tested and extended by investigating historic and geologic spit evolution and, in particular, applying wave climate analysis techniques (Ashton and Murray, 2006b) on natural examples.

\section{The Supplement related to this article is available online at doi:10.5194/esurf-4-193-2016-supplement.}

Acknowledgements. This manuscript was improved by thoughtful reviews by Albert Falqués and an anonymous reviewer. We also thank colleagues Liviu Giosan, Brad Murray, Graham Giese, and Mark Borelli for fruitful conversations. This research was supported by NSF grants EAR-0952146 and EAR-1424728.

Edited by: P. Wiberg

\section{References}

Allard, J., Bertin, X., Chaumillon, E., and Pouget, F.: Sand spit rhythmic development: A potential record of wave climate variations? Arçay Spit, western coast of France, Mar. Geol., 253, 107-131, doi:10.1016/j.margeo.2008.05.009, 2008.

Ashton, A. D. and Giosan, L.: Wave-angle control of delta evolution, Geophys. Res. Lett., 38, L13405, doi:10.1029/2011g1047630, 2011.

Ashton, A. D. and Murray, A. B.: High-angle wave instability and emergent shoreline shapes: 1. Modeling of sand waves, flying spits, and capes, J. Geophys. Res. Surf., 111, 1-2, doi:10.1029/2005JF000422, 2006a.

Ashton, A. D. and Murray, A. B.: High-angle wave instability and emergent shoreline shapes: 2. Wave climate analysis and comparisons to nature, J. Geophys. Res. Surf., 111, F04012, doi:10.1029/2005JF000423, 2006b.

Ashton, A. D., Murray, A. B., and Littlewood, R.: The response of spit shapes to wave-angle climates, in: Coastal Sediments '07, 
vol. 1, edited by: Kraus, N. C. and Rosati, J. D., 351-363, ASCE, New Orleans, LA., 2007.

Ashton, A. D., Murray, A. B., Littlewood, R., Lewis, D. A., and Hong, P.: Fetch-limited self-organization of elongate water bodies, Geology, 37, 187-190, doi:10.1130/g25299a.1, 2009.

Ashton, A., Murray, A. B., and Arnoult, O.: Formation of coastline features by large-scale instabilities induced by high-angle waves, Nature, 414, 296-300, doi:10.1038/35104541, 2001.

Bolaños, R., Jorda, G., Cateura, J., Lopez, J., Puigdefabregas, J., Gomez, J., and Espino, M.: The XIOM: 20 years of a regional coastal observatory in the Spanish Catalan coast, J. Mar. Syst., 77, 237-260, doi:10.1016/j.jmarsys.2007.12.018, 2009.

Bruun, P.: Forms of equilibrium of coasts with a littoral drift, in Coastal Stability, 5-22, Atelier Electra, Copenhagen, 1954.

Bruun, P.: Sea-level rise as a cause of shore erosion, Proc. ASCE, J. Waterw. Harb. Div., 88, 117-130, 1962.

Chawla, A., Spindler, D. M., and Tolman, H. L.: Validation of a thirty year wave hindcast using the Climate Forecast System Reanalysis winds, Ocean Model., 70, 189-206, doi:10.1016/j.ocemod.2012.07.005, 2013.

Davidson-Arnott, R. G. D., and Van Heyningen, A. G.: Migration and sedimentology of longshore sandwaves, Long Point, Lake Erie, Canada, Sedimentology, 50, 1123-1137, 2003.

Davis, W. M.: The outline of Cape Cod, Proc. Am. Acad. Arts Sci., 31, 303-332, 1896.

Evans, O. F.: Mass transportation of sediments on subaqueous terraces, J. Geol., 47, 325-334, 1939.

Falqués, A. and Calvete, D.: Large-scale dynamics of sandy coastlines: Diffusivity and instability, J. Geophys. Res., 110, C0300, doi:10.1029/2004JC002587, 2005.

Falqués, A., Calvete, D., and Ribas, F.: Shoreline Instability due to Very Oblique Wave Incidence: Some Remarks on the Physics, J. Coast. Res., 291-295, doi:10.2112/jcoastres-d-09-00095.1, 2011.

Gilbert, G. K.: The topographic features of lake shores, United States Geol. Surv. Annu. Rep., 5, 69-123, 1885.

Giosan, L., Donnelly, J. P., Vespremeanu, E., Bhattacharya, J., Olariu, C., and Buonaiuto, F. S.: River delta morphodynamics: Examples from the Danube delta, in River Deltas: Concepts, Models, and Examples, SEPM Special Publication 83, edited by: Giosan, L. and Bhattacharya, J., 393-412, 2005.

Gulliver, F.: Shoreline topography, Proc. Am. Acad. Arts Sci., 34, 151-258, 1899.

Hallermeier, R. J.: A profile zonation for seasonal sand beaches from wave climate, Coast. Eng., 4, 253-277, 1981.

Hequette, A. and Ruz, M. H.: Spit and Barrier-Island Migration in the Southeastern Canadian Beaufort Sea, J. Coast. Res., 7, 677 698,1991

Hoan, L. X., Hanson, H., Larson, M., and Kato, S.: A mathematical model of spit growth and barrier elongation: Application to Fire Island Inlet (USA) and Badreveln Spit (Sweden), Estuar. Coast. Shelf Sci., 93, 468-477, doi:10.1016/j.ecss.2011.05.033, 2011.

Inman, D. L.: Littoral cells, in Encyclopedia of Coastal Science, edited by: Schwartz, M., 594-599, Springer, Dondrecht, 2005.

Jewell, P. W.: Morphology and paleoclimatic significance of Pleistocene Lake Bonneville spits, Quat. Res., 68, 421-430, doi:10.1016/j.yqres.2007.07.004, 2007.
Jiménez, J. A. and Sánchez-Arcilla, A.: A long-term (decadal scale) evolution model for microtidal barrier systems, Coast. Eng., 51, 749-764, 2004.

Johnson, D.: Shore processes and shoreline development, John Wiley \& Sons, Inc., London, 584 pp., 1919.

Kaergaard, K. and Fredsoe, J.: A numerical shoreline model for shorelines with large curvature, Coast. Eng., 74, 19-32, doi:10.1016/j.coastaleng.2012.11.011, 2013a.

Kaergaard, K. and Fredsoe, J.: Numerical modeling of shoreline undulations part 1: Constant wave climate, Coast. Eng., 75, 64-76, doi:10.1016/j.coastaleng.2012.11.006, 2013b.

Kaergaard, K. and Fredsoe, J.: Numerical modeling of shoreline undulations part 2: Varying wave climate and comparison with observations, Coast. Eng., 75, 77-90, doi:10.1016/j.coastaleng.2012.11.003, 2013c.

King, C. A. M. and Mc Cullagh, M. J.: A simulation model of a complex recurved spit, J. Geol., 79, 22-37, 1971.

Komar, P. D.: The mechanics of sand transport on beaches, J. Geophys. Res., 76, 713-721, 1971.

Komar, P. D.: Computer models of delta growth due to sediment input from rivers and longshore transport, Geol. Soc. Am. Bull., 84, 2217-2226, 1973.

Komar, P. D.: Beach Processes and Sedimentation, Second Edi., Simon \& Schuster, Upper Saddle River, New Jersey, 544 pp., 1998.

Kraus, N. C.: Analytical model of spit evolution at inlets, in Coastal Sediments '99, 1739-1754, ASCE, Long Island, 1999.

Larson, M., Hanson, H., and Kraus, N. C.: Analytical solutions of the one-line model of shoreline change, Technical Report CERC87-15, 1987.

Leatherman, S. P.: Migration of Assateague Island, Maryland, by inlet and overwash processes, Geology, 7, 104-107, 1979.

Leatherman, S. P.: Barrier dynamics and landward migration with Holocene sea-level rise, Nature, 301, 415-417, 1983.

Limber, P. W. and Murray, A. B.: Beach and sea-cliff dynamics as a driver of long-term rocky coastline evolution and stability, Geology, 39, 1147-1150, doi:10.1130/g32315.1, 2011.

Lindhorst, S., Fürstenau, J., Hass, H. C. and Betzker, C.: Anatomy and sedimentary model of a hooked spit (Sylt, southern North Sea), Sedimentology, 57, 935-955, doi:10.1111/j.13653091.2009.01126.x, 2010.

López-Ruiz, A., Ortega-Sánchez, M., Baquerizo, A., and Losada, M. A.: Short and medium-term evolution of shoreline undulations on curvilinear coasts, Geomorphology, 159-160, 189-200, doi:10.1016/j.geomorph.2012.03.026, 2012.

López-Ruiz, A., Ortega-Sánchez, M., Baquerizo, A., and Losada, M. Á.: A note on alongshore sediment transport on weakly curvilinear coasts and its implications, Coast. Eng., 88, 143-153, doi:10.1016/j.coastaleng.2014.03.001, 2014.

Lorenzo-Trueba, J. and Ashton, A. D.: Rollover, drowning, and discontinuous retreat: Distinct modes of barrier response to sea-level rise arising from a simple morphodynamic model, J. Geophys. Res. Earth Surf., 119, 779-801, doi:10.1002/2013JF002941, 2014.

Medellín, G., Medina, R., Falqués, a., and González, M.: Coastline sand waves on a low-energy beach at "El Puntal" spit, Spain, Mar. Geol., 250, 143-156, doi:10.1016/j.margeo.2007.11.011, 2008.

Murray, A. B.: Contrasting the goals, strategies, and predictions associated with simplified numerical models and detailed sim- 
ulations, in: Prediction in Geomorphology, AGU Geophysical Monograph 135, edited by: Iverson, R. M. and Wilcock, P. R., 151-165, Washington, DC, 2003.

Murray, A. B.: Reducing model complexity for explanation and prediction, Geomorphology, 90, 178-191, doi:10.1016/j.geomorph.2006.10.020, 2007.

Murray, A. B. and Ashton, A. D.: Instability and finiteamplitude self-organization of large-scale coastline shapes, Philos. Trans. R. Soc. A Math. Physical Eng. Sci., 371, 20120363, doi:10.1098/rsta.2012.0363, 2013.

Nienhuis, J. H., Ashton, A. D., Roos, P. C., Hulscher, S. J. M. H., and Giosan, L.: Wave reworking of abandoned deltas, Geophys. Res. Lett., 40, 5899-5903, doi:10.1002/2013GL058231, 2013.

Pelnard-Consideré, R.: Essai de theorie de l'evolution des formes de rivage en plages de sable et de galets, 4th Journees l'Hydraulique, Les Energies la Mer, III, 289-298, 1956.

Pelnard-Consideré, R.: L'Hydraulique et la maîtrise du littoral: Les prévisions de l'évolution d'une plage (complément des anciennes équations proposées pour l'étude de ce problème), XVIII Journées de L'Hydraulique, Question No II (Rapport No. 7), 1984.

Petersen, D., Deigaard, R., and Fredsoe, J.: Modelling the morphology of sandy spits, Coast. Eng., 55, 671-684, doi:10.1016/j.coastaleng.2007.11.009, 2008.

Raynal, O., Bouchette, F., Certain, R., Séranne, M., Dezileau, L., Sabatier, P., Lofi, J., Hy, A. B. X., Briqueu, L., and Pezard, P.: Control of alongshore-oriented sand spits on the dynamics of a wave-dominated coastal system (Holocene deposits, northern Gulf of Lions, France), Mar. Geol., 264, 242-257, doi:10.1016/j.margeo.2009.06.008, 2009.
Roy, P. S., Cowell, P. J., Ferland, M. A., and Thom, B. G.: Wave-dominated Coasts, in: Coastal Evolution: Late Quaternary shoreline morphodynamics, edited by: Carter, R. W. G. and Woodroffe, C. D., 121-186, University Press, Cambridge, 1994.

Sanchez-Arcilla, A., Jiménez, J. A., and Valdemoro, H. I.: The Ebro Delta: Morphodynamics and Vulnerability, J. Coast. Res., 14, 754-772, 1998.

Schwartz, M. L.: Spits and Bars, Dowden, Hutchinson \& Ross, Inc., Stroudsburg, 452 pp., 1972.

Swift, D. J. P., Niederoda, A. W., Vincent, C. E., and Hopkins, T. S.: Barrier island evolution, middle Atlantic shelf, U.S.A. Part I: Shoreface dynamics, Mar. Geol., 63, 331-361, doi:10.1016/0025-3227(85)90089-1, 1985.

Valvo, L. M., Murray, A. B., and Ashton, A. D.: How does underlying geology affect coastline change? An initial modeling investigation, J. Geophys. Res. Surf., 111, F02025, doi:10.1029/2005JF000340, 2006.

van den Berg, N., Falqués, A., and Ribas, F.: Long-term evolution of nourished beaches under high angle wave conditions, J. Mar. Syst., 88, 102-112, doi:10.1016/j.jmarsys.2011.02.018, 2011.

van den Berg, N., Falqués, A., and Ribas, F.: Modeling large scale shoreline sand waves under oblique wave incidence, J. Geophys. Res., 117, F03019, doi:10.1029/2011jf002177, 2012.

Zenkovich, V. P.: Processes of coastal development, edited by: Steers, J. A., Oliver \& Boyd, Edinburgh, London, 738 pp., 1967. 